\title{
IRISH FILM AND TELEVISION - 2014
}

The Year in Review

Roddy Flynn, Tony Tracy (eds.)

Copyright (c) 2015 by the authors. This text may be archived and redistributed both in electronic form and in hard copy, provided that the authors and journal are properly cited and no fee is charged for access.

Irish Film and TV Review 2014. Introduction

Roddy Flynn, Tony Tracy

Every Plot has a Story. One Million Dubliners (Aoife Kelleher 2014)

Ruth Barton

Calvary (John Michael McDonagh 2014)

Laura Canning

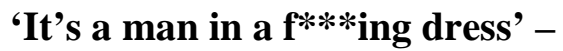

Why 11 million people cannot get enough of Mrs Brown's Boys

John Fagan

The Irreducible Difference of the Other (Vivienne Dick 2013)

Eileen Leahy

An Bronntanas [The Gift] (Tom Collins 2014)

Ruth Lysaght .....

Out of Here and What Richard Did:

Listlessness \& Inarticulacy in the Young Irish Population

Deirdre Molumby

A Poetics of Mental Illness: Patrick's Day (Terry McMahon 2014)

Barry Monahan

Irish film finance rebooted: the new Section 481

Denis Murphy and Maria O’Brien

Frank (Lenny Abrahamson 2014)

Harvey O'Brien

Quirke (2014)

Sheamus Sweeney 


\section{The Year in Review 2014}

Roddy Flynn \& Tony Tracy

I'm not a big fan of Irish movies, I don't find them to be technically that accomplished and I don't find them that intelligent. So I'm trying to get away from the description of the movie as an Irish film in a way.

John Michael McDonagh, 2014

When John Michael McDonagh's off-hand comments during promotional duties for Calvary were picked up by Irish Times journalist Donald Clarke in September 2014 (Clarke 2014), they provided a timely intervention for academics beginning courses on Irish cinema and provoked an inevitable - and at times inevitably simplistic - backlash across Irish print and broadcast media that bordered - as McDonagh later charged - on thinly veiled xenophobia. ${ }^{1}$ In a subsequent statement that put the question of Irishness and its 'privileges' at the centre of the debate, the writer/director defended his comments and his right to make them by saying:

... I was intentionally trying to position Calvary for an international audience. I didn't want it to be perceived as a small, parochial, "Irish" film. I wanted it to be seen as a universal movie dealing with universal spiritual and philosophical issues . . . What has been most dispiriting to me, however, is the low-level bigotry that has reared its head in the fallout from the interview. I am an Irish citizen, a child of Irish parents, nearly all my friends and work associates are Irish, and yet because I was born in London I supposedly have no right to comment on Irish film. ${ }^{2}$

1. The comments were subsequently widely reported and commented upon. On radio, for example: 'Leading Irish producer speaks to Newstalk about John Michael McDonagh' criticism of Irish film', http://www.newstalk.com/Irish-producer-speaks-to-

Newstalk-about-John-Michael- McDonaghs-criticism -of-Irish-film.

2. Reprinted in several outlets including: Screenwriter blog, Irish Times.
Whatever their merits - and indeed their bearing on the construction of Irish settings and characters within McDonagh's two feature films to date - the furore ignited by these comments served to underline that the meaning and significance of an Irish national cinema remains culturally charged within an era of global media flows.

It's worth acknowledging that at an industrial level, McDonagh's comments had some validity. Although the Irish Film Board (IFB) put just under $€ 1 \mathrm{~m}$ into Calvary (making it one of the Board's largest ever single investments), this was dwarfed by the British Film Institute's contribution. In crew terms, aside from McDonagh himself, several of the key Head of Department roles were filled by non-Irish personnel. It's also worth acknowledging that McDonagh has 'form' in his blunt assessment of Irish cinema. Responding to a suggestion in 2011 that The Guard could be understood as one of a number of Irish films blending comedy and violence, he emphasized that any previous films had "been done badly . . . They're all bad movies." (Digital Spy 2011). When quizzed if that included (his brother) Martin McDonagh's In Bruges, he stated that he "wouldn't count that as an Irish movie because it's set in Belgium, all the money was American, and he's [Martin] born in South London. It's only Brendan and Colin that are Irish in that film. But the Irish like to claim it as an Irish film, as if they created it, but they didn't" (Digital Spy 2011). In relation to Calvary, he explained his desire to avoid the label "Irish" for commercial - rather than cultural - reasons:

ISSN 1699-311X 
You see the problem is they [audiences] know that lots of Irish films aren't very good and they're actually hesitant about going to see the movie themselves. So when you're making a film there, you're trying to convince the Irish audience 'No, it's not like all those terrible Irish movies you've seen before (Clarke 2014).

Compelled to retrieve matters, Irish Film Board Chief Executive James Hickey spoke in moderate language, issuing a statement that welcomed the debate McDonagh's comments had engendered but politely disagreeing with them, affirming that Calvary was "a very successful Irish film, telling an exciting and challenging Irish story with Irish creative talent in front of and behind the camera" (Hickey 2014).

The debate did, inter-alia, raise larger questions about the nature of the Irish screen texts and the industries that produce them. In particular it drew attention to their increasing integration into international networks of production and distribution. Hitherto, one might assume such integration exclusively meant from above, as Ireland was instrumentalised into the global strategies of an industry still dominated by the US. Of course this remains a crucial (indeed dominant) element there is also evidence of a desire on the part of the Irish production sector to take the initiative in creating projects with the international marketplace in mind. This emphasis on the commercial/export underpinnings of state involvement in Irish film was highlighted in a speech at the Irish Film Institute's annual 'Spotlight' seminars in April 2014, when James Hickey asserted that 2014 would be a "make or break year" for the industry. Calvary was prominent in the list of Irish films Hickey cited as having the potential to 'make' an international impact (others cited included Lenny Abrahamson's Frank and Ken Loach's latest Irish project Jimmy's Hall). While it is inarguable that all of those projects provoked critical debate, their commercial success was more varied. Calvary performed modestly well in the critical US market taking $\$ 3.6 \mathrm{~m}$ over 11 weeks, screening in up to 322 cinemas across the US at its peak. Frank was far less successful taking $\$ 640,000$ over 17 weeks. ${ }^{3}$ In the UK (and Ireland)

3. Both films adopting a similar release strategy $(\mathrm{a} \cdot /$. a similar pattern was evidenced: despite very positive reviews Frank was only modestly successful,taking approximately $€ 750,000$ in the UK and Ireland, while Calvary took $€ 4.4 \mathrm{~m}$. Ironically perhaps, Brendan O'Carroll's unequivocally 'Irish' Mrs Brown's Boys D'Movie (developed from his successful BBC series without IFB development/production funding) far outstripped the performance of either taking over $\$ 28 \mathrm{~m}$ from the UK/Irish/Australia market during summer 2014 (Box Office Mojo). Such comparisons should not be taken as suggesting that these films should be primarily assessed in terms of their financial impact but rather as an acknowledgment that box office revenues reflect the extent to which these titles were able to make an impact upon audiences at home and internationally and potentially contribute to future funding decisions.

Before turning to more fully examine how Irish film and TV is adapting to the networks and platforms of digital age - what Casetti (2012) has described as the age of "relocated cinema" - we should briefly consider the span and ambitions of moving image production in Ireland during 2014. In doing so, it is crucial to acknowledge that a single unifying concept of the national (or indeed 'film') is today even more problematic than it was in 1997 (when the IFB was re-established) and that McDonagh's contrasting between 'parochial' and 'universal' is in many respects not only a false and deluding dichotomy but a tension that is central to the ways in which Irish moving-image production is conceived, produced and distributed. Ironically, there is perhaps no greater example of this tension than Calvary itself, a film which invokes an existential priest figure drawn from the French Catholic tradition of Bernanos within a highly parochial environment of Irish caricature and sharply contemporary anti-clericism. Indeed, such tensions mark the film as unquestionably the most provocative and original Irish film of 2014 with the usually one-dimensional figure of the Irish priest finally brought in from the margins of

\% single cinema release expanding to 75 screens after four weeks following initially healthy per screen averages) that did not translate into even arthousescale "mass" appeal 
cinematic representation only to find himself surrounded by a motley cast of fools, a suicidal daughter, a property developer and several would-be assassins. You could argue that there is nothing 'universal' about Calvary at all - other than death and disappointment - except, paradoxically, Brendan Gleeson's performance as a late vocation rural curate which gives the film a depth and integrity that is undeniable and unavoidable for any audience. Undeniably rooted in a contemporary Irish Catholic context, Gleeson imbues his character with a dignity and moral seriousness that transcends the film's flimsier moments and what remains is an unsettling portrait of a society that is literally and metaphorically seeking to kill its conscience.

In its narrative focus on a crises in Irish masculinity Calvary is, in thematic focus, absolutely typical of the majority of Irish film and TV. In 2014 this theme underpinned a variety of genres and formats from the micro budget, Out of Here to the comedy Gold, contemporary mental-health drama Patrick's Day, and a number of rural-set dramas including the Irish language mini-series/feature An Brontannas and Irish-Canadian co-production Stay (starring Aidan Quinn). What Connell would describe as hegemonic Irish masculinity (more colloquially referred to as 'cute hoorism') was also central to two politically-themed docudramas during the year: Charlie and The Guarantee. Taken together, these bookended a fascinating and eventful thirty year period of the Fianna Fail political party stretching from the rise and fall of Charlie Haughey during the long, lingering recession of the mid 1980s to the infamous 'bank guarantee' in September 2008 that ultimately led to bankruptcy and surrender of economic sovereignty to the 'troika' in 2010. The connivances and rivalries of the Irish male economic and political elite are central to both projects which share a structuring interest in how key moments in recent Irish history were forged in the dialectic between national and international factors. In the first, Charlie Haughey - despite his considerable ethical short-fallings - is represented as distinguishing himself from the 'gombeen' men of parochial politics through a confident and glamorous Europeanism (modeled on French arrogance) and an abiding ambition to see Dublin host the skyscrapers of international commerce (realized in the Irish Financial Services Centre). Conversely, the cosmopolitan Irish businessmen of The Guarantee are portrayed as dazzled by the same metaphorical skyscrapers of greed to the extent that the nation has become reduced to a geographical backdrop until such time as the casino of global capital withholds any more credit. Both dramas seek to explain Irish history through narrative structures familiar from British and American TV: particularly the dialogue driven political drama of Aaron Sorkin, the British political docudramas of Peter Morgan and the Machiavellian power struggles of US cable shows such as House of Cards. Both projects succeed and fail in different ways, but linking them is a reluctance to fully acknowledge and locate the specific conditions and contradictions of Irish life; notably ties of kinship and community. The Guarantee is all sheen and surface, set in a world of computer screens and 'rolling' news bulletins while Charlie, although assiduously faithful to the ebbs and flows of domestic politics, (indeed overwhelmingly so, to the detriment of drama) entirely ignores Haughey's home (but not private) life. While it does include several scenes with Haughey's mother it renders his wife and children invisible suggesting a coyness about the traditional Irish family within an otherwise generic drama about a complex and powerful men. In both projects therefore it is not the 'universal' but the local that fails to fully convince.

Frank - more fully explored and analysed by Harvey O'Brien below is, alongside Calvary, arguably the most significant Irish feature film of the year even if its status as 'Irish' is even more contested. Produced by the prolific Element films from a script by English journalist Jon Ronson and starring an international cast, its presence within this review rests on its production company (Element), significant IFB development/ production funding, the directorial presence of Lenny Abrahamson and 'Irish' stars Michael Fassbender (Irish-German playing American) and Domhnall Gleeson (with an English accent).In fact, only a very small portion of the film is set in Ireland where its cast of misfit musicians (French, British, American) led by the eponymous Frank 
attempt to record an album before travelling to perform at the hallowed SXSW festival in Austin, Texas. The film is an outlier in many respects (its oddball, uncategorizable status perhaps reflected in modest box-office takings) but it can ultimately be seen - in different ways as of a piece with both Abrahamson and Gleeson's respective bodies of work. Gleeson is a unique screen presence; slightly androgynous, courageous, never afraid to look foolish. His characters - often Irish but never in any typed sense - are rarely bound by circumstances or their past but seem open to chance and change. For Abrahamson this is another deeply humanist exploration of outsider male characters. While in films such as Adam and Paul or Garage these were located within recognizable Irish settings and socio-spatial contexts, Frank is a character who embodies 'masquerade' theories of social construction and gender to a highly self conscious/post-modern extreme, only to be 'exposed' (like many of Abrahamson's protagonists) near the film's conclusion. In a fascinating, transnational denouement, Abrahamson's film suggests that such masquerade is neither dissembling nor dishonest; on the contrary it can facilitate the articulation of a more truthful inner voice. Contravening the narrative cliché linking self-transcendence and success, Frank suggests that we are most truthful in performance. For all his oddness, unlike Adam/Paul, Josie or Richard, Frank is ultimately 'saved' by returning to his band who remain outside of dominant social structures. Questioning the contemporary link between social media and social relations the film offers a stirring and ultimately touching exploration of community in a post-national, networked society.

Returning to an institutional frame, it is notable within this thematic tension between the national and international, that an increasing number of Irish films appear to be securing prestigious industry/festival screenings and distribution within and beyond Ireland. Notable in the first category was Terry MacMahon's Patrick's Day (reviewed by Barry Monahan below) which earned the Screen Directors Guild 'Finders Series' Award ensuring it was screened in the prestigious DGA Theatre in Los Angeles to key US film distributors in October 2014. ${ }^{4}$ In January
2015 no less than five Irish-supported titles Glassland, Strangerland, The Hallow, Brooklyn and The Visit - secured screenings at Sundance, a festival regarded as a key launching pad for international arthouse films. Along with Abrahamson's maiden US release Frank, a number of lower-key titles secured US distribution on a variety of formats: Life's a Breeze, starring Fionnula Flanagan and Pat Shortt opened in US cinemas in September 2014 before moving to VOD. Cartoon Saloon's Song of the Sea (which won't be released in Ireland until summer 2015) received a limited US theatrical release; Ivan Kavanagh's horror feature The Canal and Des Doyle's warmly-received documentary Showrunners screened at Tribeca and Donal Foreman's impressive micro-budget debut Out of Here (discussed in these pages last year) had a small Irish release before moving to Vimeo VOD.

VOD is in fact slowly but radically altering the distribution landscape of Irish cinema. In 2014 UK arthouse cinema group Curzon, added a plethora of examples of what might be termed Irish repertory cinema (including Eden (2008), Waveriders (2008), Parked (2010), Snap (2010) and Barbaric Genius (2011)) to their online offering Curzon Home Cinema. Netflix Ireland's decision to add The Stag, Calvary and Frank to their list of titles was interpreted as a serious vote of confidence in the audience pulling power of those films. Netflix went further in February 2015, acquiring global rights to Jadotville, a feature based on the 1961 siege of an Irish battalion on UN duty in the Belgian Congo and featuring Jamie Dornan (The Fall/50 Shades), a move which suggested that the company could no longer afford to take their Irish subscribers for granted and had identified domestic content as a key development strategy.

We can say that 2014 saw a resurgent confidence and optimism within the Irish film and TV sector; expressed in producer James Flynn of Octagon Films comment that "We are in a golden age of sorts ... hopefully things will get

4. Patrick's Day' Wins Screen Directors Guild 'Finders Series' Award. http://filmireland.net/2014/08 /25/patricks-day-wins-screen-directors-guild-findersseries-award/ 
even better." The figures seem to support this view: the overall value of independent (i.e. nonbroadcaster) film, television and animation production in Ireland reached $€ 195 \mathrm{~m}$ in 2014, up $6.5 \%$ in 2013 (and a whopping 37\% in 2012) (IFB 2015). The Irish Film Board were clearly looking to build on this: by January 2015 they were engaged in a consultation with the indigenous industry to inform a new Five Year strategy. Notably, the language used by Bill O'Herlihy and James Hickey at the announcement of the Board's schedule for the coming year explicitly identified IFB as a screen industries development agency (as opposed to one narrowly focused on promoting film culture), with a particular emphasis on the need to develop the level of TV drama with international sales prospects.

The optimism about an upturn in activity was evinced in a number of other ways. Several Irish directors who have been quiet of late (at least within Ireland) began work on indigenous projects as Jim Sheridan, Paddy Breathnach, John Carney and John Crowley commenced shooting on The Secret Scripture, Viva, Sing Street and Brooklyn respectively. In November 2014, the star of the animation sector, Brown Bag Films announced the establishment of a subsidiary in Manchester employing 40 people. New countylevel Film Commissions continue to spring up around the country. In June 2014, 24-7 Camera, a major supplier of camera equipment to UK television producers (including the Sky produced Moone Boy) opened a Dublin branch directly providing to the Irish market. Most telling, however, were repeated expressions of concern that Ireland lacked sufficient studio space; even after the Titanic Studios facility in Belfast which has hosted every season of Game of Thrones secured permission in August 2014 to add 100,000 square foot (equivalent in size to southern studios Ardmore and Ballyhenry combined) to its facility. ${ }^{5}$

5. This focus on studio space seems remarkable: only three years ago this editorial started by raising questions over the future viability of Ardmore Studios after the opening of the competing Ballyhenry Facility. Yet in June 2014, the Film Board issued a call for expression of interest in promoting audiovisual $\%$.
There was also encouraging news for the smaller screen. After years of retrenchment and cost-cutting, RTÉ earned its first profits $(€ 1.1 \mathrm{~m})$ since 2007. UTV Ireland's securing of public service status from the BAI in December 2014 guaranteed it a favourable slot on Saorview platform and cable/satellite EPGs, forcing TV3 to significantly up their indigenous output. Although this is largely constituted by reality/lifestyle genres, (often based on wellestablished UK formats such as Blind Date and Gogglebox), it also prompted a significant commitment ( $€ 7 \mathrm{~m}$ for 80 episodes over two years) to the channel's new domesticallyproduced soap Red Rock. The early months of the show has surpassed expectations, winning 411,000 viewers on its debut. By contrast, UTV Ireland, which has relied heavily on its flagship evening news programme to distinguish it from not just RTE and TV3 but also its former incarnation has initially struggled to win market share. Watch this space.

\section{Conclusion}

Our focus on the last 12 months notwithstanding, casting an eye over the past two decades from the vantage point of 2015 reveals patterns. There is now a broad sense that there is a generation of Irish people who have grown up with the assumption that there is a sustained and secure culture/industry of Irish screen production and an acceptance that today this culture/industry is structured in tension between the local and 'universal'. This is reflected at one level in the remarkable emergence onto an international stage

5. $\%$ studios. In November 2014, Siun Ni Raghallaigh, Chief Executive of Ardmore went so far as to suggest that there was a need to double (i.e. increase by 100,000 square feet) the availability of studio space (plus a further 150,000 of support buildings) in Ireland. In the same month the Film Limerick screen commission, in the context of promoting Limerick as an alternate hub of screen production raised the prospect of creating a studio to be located inside the 300,000sq ft former Dell factory - a symbolic repurposing and statement about how the screen industries in Ireland have thrived throughout an economic crisis which has seen off notionally more stable manufacturing industry. 
of a plethora of Irish actors who are as likely to be seen in 'Irish' stories as films/TV shows which are part of global media culture: Saoirse Ronan, Andrew Scott, Jack Reynor, Jamie Dornan, Michael Fassbender, Aiden Gillen, Chris O'Dowd and Domhnall Gleeson (among others). Increasingly this is also the case behind the camera too: Aisling Walsh, Dearbhla Walsh and Neasa Hardiman are all established directors on UK TV who work when possible in Ireland. Productions like the Australia-set Strangerland and Sky's Fortitude feature a number of Irish HoDs. Andrea Arnold uses IADT graduate Robbie Ryan as her go-to Director of Photography whilst two of the biggest global movies of 2014/15, Godzilla and Fifty Shades of Grey were both lensed by Antrim man Seamus McGarvey. Perhaps the most spectacular leap in this regard this year was that of Ciaran Foy, who moved from directing the low-budget Irish horror
Citadel in 2012 to the Ethan Hawke hit horror Sinister sequel. It is notable too that Ireland is increasingly a site for post-production work on both local and international productions: Roy and Moone Boy were both posted by Egg Post Production as were Miss Julie and Young Ones at Windmill Lane.

Cumulatively, the increasingly established position of this talent and these companies (amongst countless others) suggests a diversified and broad-based industry which has finally 'bedded in' after years of turbulence and uncertainty. The challenge for content makers in film and TV is to convincingly balance this tension between the local and universal in ways that neither disown the experience and specificity of Irish culture and nor take for granted the long journey towards the established, vibrant and hugely talented Irish moving image sector we see today.

\section{Works Cited}

Casetti, Francesco. 2012. "The Relocation of Cinema", European Journal of Media Studies, Nov 22 http://www.necsus-ejms.org/the-relocation-of-cinema/

Clarke, Donald. 2014. “Are you sending back your IFTA, John Michael McDonagh?” Screenwriter blog, The Irish Times, Sep 15 http://www.irishtimes.com/blogs/screenwriter/2014/09/15/john-michael-mcdonagh-deniescalvary-is-an-irish-film/

Digital Spy. 2011. "John McDonagh talks The Guard”. Video, Uploaded August 19, viewed February 272015, https://www.youtube.com/watch?v=eTeXO3ojpko.

Hickey, James. 2014. "James Hickey Welcomes Recent Debate on Irish Film and Speaks about his Optimism for the future of the Industry", Sep 22

http://www.irishfilmboard.ie/irish_film_industry/news/James_Hickey_Welcomes_Recent_Debate_on_Irish_F ilm_and_Speaks_about_his_Optimism_for_the_future_of_the_Industry/2542

Irish Film Board. 2015. "Irish Film 2015, In the Spotlight", Dublin: Irish Film Board, January.http://www.irishfilmboard.ie/files/reports/IFB_Catalogue_2015_Digital.pdf

Tony Tracy lectures at Huston School of Film and Digital Media, NUI Galway where he is director of the BA Film Studies programme. His research interests include Irish-American, Irish and silent cinema. Recent publications include Masculinity and Irish Popular Culture: Tiger's Tales (Palgrave 2014) coedited with Conn Holohan.

Roddy Flynn is a lecturer on film and television at the School of Communications, Dublin City University. 


\section{Every Plot has a Story. One Million Dubliners (Aoife Kelleher 2014)}

Ruth Barton

The success story that was One Million Dubliners raises a number of interesting issues around the appeal of indigenous productions to Irish viewers. As elsewhere, documentary has enjoyed a considerable revival in Ireland, now regularly claiming a place on cinema screens and in awards ceremonies. Other recent examples include Broken Song (Claire Dix 2013), Pyjama Girls (Maya Derrington 2010) and The Pipe (Risteard O'Domhnaill, 2010). One Million Dubliners is thematically the least radical of these but was certainly the most widely viewed. It received a theatrical release at the Irish Film Institute (IFI), where the original week's run was extended to two weeks and included a number of additional screenings. One Million Dubliners sold 1,961 seats, which translates to a gross of $€ 12,972$ (O'Flynn 2015). RTÉ was quick to realise the documentary's potential and ran advertising for the screening while the film was still playing theatrically. (It closed within 48 hours of the television broadcast, a situation that has traditionally been regarded as box-office death but here proved otherwise.) The television screening reached 254,000 viewers or $27.21 \%$ audience share at its high point, with people actively seeking it out as a consequence of the Twitter campaign (Lysaght). Both Sunniva O'Flynn at the IFI and Rachel Lysaght at Underground Films emphasise the importance of social media to the film's success (O'Flynn 2015; Lysaght 2015).It was also notable for being distributed by the producers, and thus able to access funding under the Irish Film Board's "Direct Distribution" scheme (Irish Film Board).

Canny marketing, however, still is no guarantee of success and we need to look further to understand why audiences so warmly embraced a film about a burial ground and crematorium. The topic of the documentary is Dublin's Glasnevin cemetery and much of it is seen through the eyes of its resident historian, Shane Mac Thomáis. One Million Dubliners opens with preparations for a funeral and segues swiftly to the dawn arrival of a coach load of American tourists who have just been picked up from Dublin airport. It closes with the burial of Mac Thomáis, an unexpected revelation that may come as a shock to the viewer and which belatedly explains the identity of the coffin at the opening.

One Million Dubliners was the joint winner of the "Best Irish Feature Documentary" at the 2014 Galway Film Fleadh and was voted "Best Irish Film" in an on-line competition held by the Irish Times' entertainment supplement "The Ticket" in December 2014. In interview, its director, Aoife Kelleher, has said of it that: "The themes are universal, but I do think that there's something very, very Irish about the tone. There's a quirkiness and a certain way of looking at life and death that's very Irish. I'd love to see it travel, but for me, the most important audience is an Irish one. That's who it was made for, really" (Murphy 2014).

Kelleher's film, as she suggests, integrates into its diegesis and aesthetic certain common representational signifiers of Irishness. Perhaps surprisingly, the fabled Irish attitude to death is the least obvious of them. The rituals of the wake and the practice of "open coffin" have become increasingly anachronistic, particularly among younger people and in urban areas. Cemeteries the world over are now highly visited, and no evidence exists to suggest that Glasnevin's visitor rate is exceptional. In keeping with changes in attitude to religious practices and beliefs, the interviewees express a range of opinions about their own wishes as to the disposal of their bodies and to whether or not they anticipate moving on to an afterlife. Some hold on to conventional religious beliefs, others voice quite opposite

ISSN 1699-311X 
opinions. In one sequence, Derek O'Brien, a wheelchair user, visits the grave of singer Luke Kelly and, with complete sincerity, explains how he looks forward to meeting Kelly in the next world. Yet, viewers are neither nudged towards sentimentality in their response to these interviews nor treated to a vision of a culture that shares common attitudes to death. Much more so, Irish society is shown as modern and plural, indistinguishable in this respect from many other Western societies.

In other ways, however, the Irishness of One Million Dubliners permeates its narrative. On a simple content level, its showcasing of the tombs of Michael Collins, Daniel O'Connell, Brendan Behan, Maud Gonne McBride and Countess Markievicz and those of other public figures positions the cemetery as a repository of Irish history. At the same time, its inclusion of "ordinary people", such as the young woman who comes to pay her respects to the grave of her mother, recognises that Irish history is not just a narrative of charismatic leaders and bucolic artists, but of others whose names will be unknown to the wider population. A space within the cemetery dedicated to unbaptised infants, the Holy Angels plot, invokes another history, of the discovery of mass unmarked graves across the country. In conventional Catholic teaching, such infants could not be buried on hallowed ground as they were still in a state of original sin. Thus, they resided in limbo, caught between heaven and hell. Glasnevin's own part in this tradition offers something of a comfort, however, in that it did lay aside an area for these burials, attenuating the national narrative of shame with a small note of compassion. Glasnevin here is, in Mikhail Bakhtin's terms, a chronotope, where time and space are linked, "a piece of human history, historical time condensed into space" (Bakhtin 1986: 49). History/histories flow through the cemetery, defining it both temporally and spatially. Other histories are also evoked in the documentary, notably via Shane Mac Thomáis' voice-over. Mac Thomáis' father, as he mentions, was the Republican, Éamonn Mac Thomáis, a historian, editor, broadcaster and well-known figure in Irish public life until his death and burial in Glasnevin in 2002. Mac Thomáis is at once tour guide and raconteur. As the film's tagline promises, "Every Plot Has a Story" and most of these are told by him. Always nattily dressed, his populist recounting of the tales surrounding the many burials and crypts dispenses with the elitism of conventional scholarly history. $\mathrm{He}$ jokes with schoolchildren and jollies along the cold, jet-lagged American tourists. The revelation of his untimely death at the end of the film is thus a shock, a sudden merging of historical time and real time, a reminder of ordinary loss. Yet, it is also toned down - an editorial decision omits the information that Mac Thomáis committed suicide in the cemetery.

Doreen Massey has written of the need to recognise space as dynamic and unbordered, as articulating social relations:

\begin{abstract}
which necessarily have a spatial form in their interactions with one another. If this notion is accepted, then one way of thinking about place is as particular moments in such intersecting social relations, nets of which have over time been constructed, laid down, interacted with one another, decayed and renewed. Some of these relations will be, as it were, contained within the place; others will stretch beyond it, tying any particular locality into wider relations and processes in which other places are implicated too (Massey 1994: 120).
\end{abstract}

Written before the now widely understood concept of the networked society, Massey's words anticipate how audiences productively employ social media to create their own linkages to cinematic narratives. Here, the cemetery's space was to become claimed and reclaimed by viewers who went on-line in their droves to tell their own stories of loved ones buried in Glasnevin.

The camerawork, too, has an unboundedness that would appeal to Massey's vision of place. An early overhead camera movement (shot with a drone) glides over the graves, opening up the area rather than closing it down. The title, One Million Dubliners, further endows the space with connotations of community, the slightly oldfashioned use of "Dubliners" suggesting a lineage that is at once diffuse and specific. Indeed, it offer a belongingness after death that many may not experience in their current earthly existences. 
One Million Dubliners played against the backdrop of headline news of homelessness and at a time when many of Ireland's inhabitants were expressing intense feelings of alienation from national government.

Another, highly engaging, segment concerns the "mysterious French lady" who comes to visit the tomb of Michael Collins. Accompanied by her friend Phuong Tran Thi Binh, she explains to camera why she loves "Michael", whose story she came across after viewing Neil Jordan's Michael Collins (1996). Her assumption of familiarity aligns her with the dynamics of fandom and its promise of intimacy with a stranger. This is, however, a particularly postmodern fandom in that Véronique's only experience of the object of her love is the filmic construction of that historical person. As one of the florists explains, "A lot of foreign people fell in love with him [Collins] from the movie". If the reference to Irish cinema is concrete in this sense, in another it is evocative of a long tradition of representation. Véronique assumes the role of the foreign, often eccentric "other" who frames Irish history and identity through a discourse of exoticism. However, just as much as her gaze calls the indigenous Irish into being, so the film offers a contrapuntal gaze, as the Irish look back. Of the various looks of the film, the most obvious counterpoint to Véronique's is that of the florists, Claire Hickey and Catherine Kearns, who run the shop at Glasnevin's entrance. They have a proprietary positioning within the play of looking and utterance that invites the local viewer to align themselves with them and thus to look back as knowing insiders.

To conclude, One Million Dubliners' appeal can be ascribed to its careful interweaving of tropes of the Irish past into a present that acknowledges and offers consolation for multiple passings. Where its conservatism becomes evident is in its unwillingness to consider how the cemetery will adapt to Irish identity patterns in the future. The film does not raise the question as to how successfully it will integrate, or, even, has integrated, Muslim and other non-Christian believers into its promise of belonging.

Another of its consoling narratives is selfsufficiency. In the documentary, Shane Mac Thomáis explains the financial imperatives that lay behind the policy of persuading the next of kin of famous figures to consider Glasnevin as the final resting place of their loved ones, while Philip Ryan, Grounds and Facilities Manager, talks of how dwindling government subsidies forced management to embrace commercialisation. Despite this imposition of neo-liberal policy-making, everyone is coping.

To label One Million Dubliners conservative is not a critique so much as an observation. In many respects, such as Ray Harman and Hugh Rodgers' light-touch score with its mix of the elegiac and the contemporary, Kelleher's film shows itself willing to break with convention (another director might well have taken the easy option of choral accompaniment). Rather more, it is a film that offers its audiences a space of their own to contemplate loss.

\section{Works Cited}

Bakhtin, Mikhail M. 1986. Speech Genres and Other Late Essays. Ed. Caryl Emerson and Michael Holquist. Trans. Vern W. McGee. Austin: University of Texas Press.

Massey, Doreen. 1994. Space, Place and Gender. Cambridge: Polity Press.

Murphy, Lauren. 2014. “A ‘very Irish' film about matters of life and death”. The Irish Times, 3 November. 13.

Irish Film Board, 'Direct Distribution', http://www.irishfilmboard.ie/funding_programmes/Direct_Distribution/87 [accessed 5 February 2015]

Lysaght, Rachel. 2015. Email correspondence with the author. 5 February.

O’Flynn, Sunniva. 2015. Email correspondence with the author. 4 February.

Ruth Barton is lecturer in Film Studies at Trinity College Dublin and the author of a number of books on Irish cinema. Her most recent monograph is Rex Ingram: Visionary Director of the Silent Screen (University Press of Kentucky, 2014). 


\section{Calvary (John Michael McDonagh 2014)}

\section{Laura Canning}

In this ambitious attempt at something between a Bergman-esque mystery play and a nihilist Western, McDonagh steers his course through a vastly more complex moral path than did his international hit The Guard (2011). While superficially it takes the form of a suspense thriller - Fr. James Lavelle (constant collaborator Brendan Gleeson) has been informed in the confessional by an unknown former victim of clerical abuse that he will be killed in a week - it is less the identity of his putative murderer which not at odds here, but rather he negotiation of Lavelle's seemingly inevitable martyrdom. And martyrdom it is; we are given to understand from the beginning that Lavelle is, as he is sneeringly referred to later in the film, "the good priest", punished for the sins of the Catholic Church.

As seems to be par for the course with McDonagh, it is a potent mixture of the provocative and engaging, and the repellently boorish. Shot mainly in Sligo by Larry Smith (Bronson, Only God Forgives), the landscapes avoid overblown John Hinde lushness, instead giving us wild expanses which, if they veer a little too close to Bord Fáilte ads, emphasising empty beaches and solitary surfers, at least give us a recognisable contemporary Ireland. It is an Ireland which also calls out to that urrepresentation of the West of Ireland, The Quiet Man (John Ford 1952); not simply in geographical terms, but in several scenes which recall, and then transform for contemporary contexts, thematic elements. Lavelle, fishing in the river as he speaks with his daughter from a pre-ordainment marriage (Kelly Reilly), is framed in ways which recall Ward Bond and Maureen O'Hara's similar conversation; a 'hooley' in the village pub - the only apparent intrusion of traditional Irish culture into the film's world - is punctuated by an instance of quasicomic violence in which a priest is punched. However, whereas in The Quiet Man the priest becomes a powerful figure of civic reconciliation, and eruptions of brawling serve as catharsis, symbolically uniting the community, in Calvary a bleaker picture emerges.

McDonagh is clearly making links here between Ford's Wild West and the mythic 'True West' of Irish cultural nationalism; light references to "Apaches" and "Arapahoe" serve as linguistic tokens of this. However, it is in the underlying sense of moral lawlessness which dogs the priest's encounters with his parishioners as he bids to identify his persecutor, that the parallel between the two wests is made overt. When the local Garda Inspector provides him with a gun and a no-questions-asked alibi, the sense of Lavelle as a gunslinging cleric conducting a solitary moral crusade in a dangerous town further reinforces this.

As with McDonagh's previous work, elements of black comedy pervade the film, as well as a strand of puerile humour which assumes that two priests using the word "felching" must be intrinsically hilarious. In truth, these, and the putative suspense-thriller structure, sit uneasily with the deeper - and more interesting - matters which lie beneath. His reliance on hokey narrative interventions, one character asking as we enter the final phase of the film "How's that for a third act revelation?" reads not as reflexivity but as egotism, the act of a writer who cannot bear for their powerful presence to be overlooked; his dialogue is as archly overwrought and wearying to listen to as The Guard's. It is also difficult to see the central principle of the film, the killer's assertion that "[t]here's no point in killing a bad priest. But 
killing a good one? That'd be a shock, now" as anything other than a set-up, a narrative hook, as opposed to a genuine moral or ethical problem.

There are profound difficulties with regards McDonagh's representations of gender, race, and sexuality. Lavelle's daughter Fiona, recovering after post-love affair suicide attempt, is merely a wounded bird who serves as a reminder of Lavelle's former 'normal' non-celibacy, orienting him in reassuringly conventional heteromasculine terms. Provocative femme fatale Veronica is of interest only in terms of her (defined as kinkily outré) sexual practices. Interestingly, male desire (whether thwarted, brutal or sad) is treated here with compassion no matter how destructive; socially dysfunctional Milo parrots slogans about joining the army, outlining that his problem is "[n]ot getting laid. It's starting to make me feel really angry towards women." In other hands, this could serve as an attempt to unpack male aggression and its consequences - and McDonagh takes it in an interesting direction with Lavelle's assertion that "I've always felt there's something inherently psychopathic about someone who joins the army in peacetime" - but instead the script returns to joking about "chicks with dicks." McDonagh's cast of local eccentrics are casually misogynistic and racist; African immigrant Simon is merely treated as a way for Lavelle to demonstrate his superiority over the cringingly uncomfortable Fr. Leary (David Wilmot). Most uncomfortably, in what must surely be an effort on McDonagh's part to intensify the conflict between the priest and the community, the supposed "good priest" Lavelle trivialises Simon's legitimate critique of the Catholic church's actions in Africa - "You cannot tell me what to do. We're not in the Missions now...Are you going to cut off my hand if I disobey?" - by responding "Black people, white people, blah blah blah."

However, in a somewhat unlikely turn, McDonagh's blistering analysis of post-crash Ireland rings resoundingly true. All sense of community seems absent here, every character holding onto their own secrets, each filled with private rage, pain, and emptiness. Self-described financial "colossus"-turned country squire Michael Fitzgerald (Dylan Moran) is a caricature (as are so many of the supporting characters) but a complex one. Assessing his possessions in simple terms of their relative expense, utterly distanced from the abandonment of his wife and children, and dismissive of philanthropy as anything other than "the expiation of guilt", he is not immune to philosophical crisis. As he contemplates urinating on his disliked Breughel simply "so I can have some sort of spiritual revelation" Lavelle comments that "People like you have pissed on everything else, I suppose." It is from Fitzgerald that the most damning critique of Irish society comes; describing his pre-economic collapse exit from the financial markets as "the perfect getaway", he notes that

they'd have to charge half the financiers in Ireland, and half the bank managers along with them, and then troop into government and arrest those cunts as well. And we all know full well that's not going to happen. There'll be no punishment forthcoming for a man such as myself. There never is.

The Catholic church is linked with these structures of corruption and oppression in inescapable ways; Inspector Stanton (Gary Lydon) recounts the tale of having been redeployed to the west as a young Garda in punishment for attempting to bring a case against a paedophile priest; Brendan Lynch (Pat Shortt) raises the bank-enforced foreclosure of his pub in bitter terms: "How come I never hear your mob preaching about that?...Those are sins too, aren't they? I suppose when you've a history of screwing the jews out of their money, and collaborating with the Nazis, it's like the pot calling the kettle black." Lavelle's defensive posturing in reply "I suppose it is. Getting full use out of your library card there Brendan?" reveals that indeed, Lavelle may be "the good priest" but is as prone to self-justification as any other mortal.

Indeed it is in its use of Brendan Gleeson, and the questions at the heart of his dilemma - should he save himself by fleeing, reveal his persecutor, or hope that he can appeal to his rationality and free will in time to change his mind - that Calvary is at its most interesting and complex. Positioned and structured as the slow procession to martyrdom of one good man, the inability of the film to manage theoretical or psychologic 
disjunctures between Lavelle as a man and Lavelle as priest start to crack it open. The rage the community directs towards him is not condemnation of him as a man, but as a representative of the Catholic church; this serves both its narrative function (of those threatening him, one of them must be the killer), and its crudely symbolic function (they are the agents of his Christ-like martyrdom). However, Lavelle is the furthest thing possible from the 'bogeyman priest'; the film tries so hard to make him 'relatable' as a contemporary man - to avoid alienating its presumed audience of religionavoiding 18-35 year olds? - that it becomes difficult to understand why this man became a priest at all.

Certainly his vocation is never literalised; he admits "I have no answers"; he speaks to parishioners in terms which more closely align with humanist perspectives, such as when he says to a grieving widow "What is faith? For most people it's the fear of death, nothing more than that." This woman - notably a French, rather than Irish Catholic - is one of two characters given a position close to more 'familiar' traditional doctrine when she says of others in crisis "They lose their faith? It must not have been much of a faith to begin with, if it is so easy for them to lose." The second is, more grotesquely, a former student (and cannibal serial killer) whom Lavelle visits in prison; hopeful that if he repents he may go to heaven and apologise to his victims, he asks Lavelle if "God made me, didn't he? So he understands me." Lavelle in reply takes not a doctrinal position, but an almost psychotherapeutic one: "If God can't understand you...no one can". While framing the character in these terms works well to place the priest on ground recognisable to contemporary secularhumanist audiences (he is more Fr. Therapy than Fr. Trendy), it creates a problem of narrative, and of representational politics.

The question of whether McDonagh resolves this narrative problem is difficult to answer. As Lavelle appears to disavow (or at least avoid) many of the doctrinal positions of the Catholic church, but is being punished for the sins of that church, the question of whether he is being punished as a man or a priest becomes inescapable.
His persecution as a man is a crime, morally, but the focus on his suffering - such as when an innocent conversation with a young girl results in her father screaming abuse at him - obscures or undercuts the legitimate and well-focused anger against the Catholic church which the film also holds in tension. The community's resentment towards him cannot therefore be seen as rage towards the church, but as a personal calvary; this both drains the political elements of the film of their energy, and reinforces the impotence of the Irish people in the face of deeply structuralised corruption and inequality. However, this is a performance of great depth and complexity, and it seems no coincidence that it is also the least verbose: it seems that if McDonagh could rein in his inner chatterbox (or his outer show-off) he could produce fine and subtle work.

Gleeson, the rock around which all waves must flow, gives the film a gravity and emotional richness that Mc Donagh's cardboard cut-out village eccentrics cannot match, and the contrast between the two modes of address fatally destabilises it. The narrative demands that almost everyone Lavelle encounters must have a reason to kill him; the result is, unfortunately, that characters' motivations seem mechanical, and they are given McDonagh's grandstanding speeches with which to work rather than emotionally or psychologically convincing encounters.

It is frustrating that McDonagh cannot seem to link character and narrative without lapsing into distracting, sub-Synge wordplay, and therefore paradoxical that while the most impressive aspect of the film is Gleeson's performance, some of the grandstanding scenes - as opposed to those which rely on contrived parochial shenanigans, or self-conscious wordplay - are very powerful. The final showdown - for it is shot precisely in such gunslinging terms - sees the abuse victimturned-avenger point out to Lavelle that for all his talk of virtues, he cried for his dead dog, but not for the children in the newspapers. The stories of abuse, cover-ups and structural corruption, have not touched Lavelle, whose martyrdom ends on a somewhat ambiguous note; the abuse survivor is the real victim here, not the priest - but the camera refuses to linger on him, 
turning instead to a strangely Angelus-like montage of the supporting characters.

McDonagh's sense of anger and loss seems genuine, and if the film implies that in abandoning the Catholic church we have lost ourselves to the worship of sex and money, he refuses to give us any real alternative, certainly not in the benevolent conscience-pricking of God's own sheriff. Philosophically, the film veers towards nihilism: if the church and state are corrupt and rotten, only personal honour and compassion remain, says this individualist perspective; but individualism can be fatal, as Fr.
Lavelle, for all his virtues, discovers. As he goes to his fate, following a sparingly-shot preparation sequence, Lavelle calls his daughter from a payphone to tell her "I think there's too much talk about sins, to be honest. And not enough talk about virtues...Forgiveness has been highly underrated." Calvary is undeniably muddled and problematic, but takes a brave step towards maturity for the writer-director, and with a performance at its heart that conveys more compassion than McDonagh's words seem capable of.

Laura Canning is a lecturer in the School of Film and Television at Falmouth University, Cornwall, UK, and alumnus of Dublin City University. 


\section{'It's a man in a f***ing dress' - Why 11 million people cannot get enough of Mrs Brown's Boys}

John Fagan

It's a big, silly, thick show - part pantomime, part It's-a-Knockout, part 1980's sitcom Bread, part CBeebies. It's the show that the BBC have been dying to commission for years, but couldn't find anyone from their usual flock of writers who'd turn in anything as knowingly base (Dent 2012).

With its emphasis on profanity, drag, vulgar sexual humour, physical clowning and sentimental family values, Mrs Brown's Boys (2011-) is a show that unashamedly taps into an end-of-the-pier comedy tradition and the un-pc aesthetics of 1970s/80s sitcom. It's also a sitcom that demonstrates a knowing awareness of the aesthetics of the sitcom form, relentlessly breaking the fourth wall for comic effect. A massive hit, this tale of a working class 'blue' comic in a dress, tending to her brood has secured audiences (and audience numbers, 11 million at Christmas 2013) that the BBC haven't seen since the heyday of Only Fools and Horses (BBC 1 1981-2003). It's a show that, as evidenced by TV critic Grace Dent's comments, has been reviled by many UK and Irish critics, affronted (or baffled) by the appeal of its supposedly 'low' comedy of drag, incessant use of the F-word and throwback 1970s comic sensibilities. Indeed editorials in previous years of this review have repeatedly speculated as to the nature of the show's extraordinary popularity. In this piece the attempt to identify the appeal of the show primarily considers how the show emotionally, culturally and aesthetically connects its audience to its comedy.

\section{The 'Forgotten' Audience}

One challenge to exploring Mrs Brown's Boys audience is the remarkable absence of research on the specific make-up and character of its viewership (and, as Freidman et al, note on comedy audiences in general, 'a woefully under- researched area' (2011: 123)) so discussion here must be speculative. However, as Danny Cohen, BBC 1 controller in 2011 noted, Mrs Brown's Boys' audience is one that had gone 'missing' in recent years, it's working class roots and sensibilities largely absent from mainstream BBC television comedy, ignored in favour of a preponderance of middle class sitcoms (My Family BBC 1 2000-11, Outnumbered BBC 1 2007 ongoing etc.) (Friedman et al 2011).

It was this 'forgotten' TV audience that Mrs Brown's Boys soon-to-be producer, Stephen McCrum, rediscovered when he attended the stage version of O'Carroll's show one rainy evening in Glasgow (The fancarpet 2011). Here was a working class viewership not catered for by television's obsession with self-aware, mock documentary comedy (The Office BBC 2 200103) etc) or 'smart' working class comedy (The Royle Family BBC 2 1998-2012, 2014). O'Carroll himself was keenly aware of this, seeing Mrs Brown's Boys as appealing to,

the audience that comedy forgot... somebody at the $\mathrm{BBC}$ read in a magazine that comedy is the new rock'n'roll. And they actually believed that and started pitching it only to the 18- to 25-yearold market, and left the rest behind (Langley 2014).

Yet the mere fact of a forgotten audience awaiting rediscovery could not guarantee the success that Mrs Brown's Boys has enjoyed. After all, new sitcoms 'die' with astounding regularity (London Irish (CH4 2014) anyone?). The show's engagement with its audience works

ISSN 1699-311X 
effectively because of fascinating discourses at work in the roots of Mrs Brown's Boy's humour; on sexuality and how audiences engage with the sitcom machine as a popular comedy form.

\section{The Merry Widow - Mining Female Sexuality in Mrs Brown's Boys}

Mrs Brown's Boys is a show that places sex, bantering about it, remembering it, looking for it, at the centre of its comedy. So far, so sitcom it's a form that has often relied on getting its laughs from the double entendre and the slapstick of bosoms and bottoms. Porter (1998) notes how traditional sitcoms of the 1970s and 80 s (to which $M B B$ undoubtedly owes a debt) saw female desire as essentially voracious and unsettling; presenting as either the busty blonde male fantasy (Barbara Windsor in any Carry-On film) flaunting their overt sexuality or as unattractive post-sexual spinsters or frustrated married women (Al Bundy's wife Peg in US sitcom Married with Children (Fox 1987-97). Mrs Brown's Boys however reclaims female desire from this most un-PC of comic DNA, giving a joyous voice to middle-aged women (O'Carroll's long time audience). In Mrs Brown's world, the older woman, often seen as post-sexual, with desires no longer validated by society, becomes the subject of comic celebration.

Reflecting Freud's (1976) relief theory, Mrs Brown's Boys presents its audience with comedy which gives vent to normally unacknowledged desires (widows/aged mothers wanting sex). Centre-staging the sexual desire of the supposedly no longer desirable, delving deep into its emotional roots and playing its vulgarity for maximum enjoyment is fundamental to the show's appeal. Mrs Brown (and her best friend/comic foil Winnie) speak of sex variously as a melancholic experience of lost passion, unclaimed 'organisms', repressed desires, and equally a lustful, joyous delight in remembering youthful sexual adventure,

Mrs Brown: I remember one night, me and Redser, walking along the beach at Portmarnock. He started chasing me into the sand dunes...so I was lying there, I said (flirtatious, sexy voice), 'What do you want?' (laughs remembering). He said I want your knickers around your ankles (flirtatious laugh). I had to get my feckin' handbag and put them on (Mrs Brown's Boys S2 Ep 1 Mammy Pulls It Off 2011).

Other exchanges though go deeper into unfulfilled desire, perhaps best illustrated by Winnie discussing her two solitary 'organisms' (orgasms), an experience that had so far eluded Mrs Brown,

Winnie: I had this feeling like a wave came over me. Mrs Brown: A tsunami?

Winnie: It was like getting ten early numbers in the bingo and you just know something's coming up.

Mrs Brown (in wonder): Ten early numbers?

(Mrs Brown's Boys S2 Ep 2 Mammy's Coming 2012)

Interestingly, the audience laughter builds and builds throughout this tale, becoming louder and more appreciative with each revelation. It's a laughter that delights in Winnie's description of her pleasure, a rolling wave of shrieking laughter, pushing itself onwards as Winnie heads toward the routines climax (pardon the obvious pun). Acknowledging that the female orgasm is no longer a socially unacceptable topic for discourse (and hence repressed), we can adapt Freud's (1976) relief theory somewhat as this uninhibited, indeed, joyous exploration of the orgasm manifestly prompts laughter as a kind of 'psychic expenditure' (ibid.: 168), released by rendering comedic the emotional complications underlying ideas of female desire. In short, Mrs Brown and Winnie tell it like it is about being a post-sexual, desiring but no longer desirable, middle-aged woman. Finally, this mining of female desire for comic impact unleashes what we might call a community of feeling that does much to bind the audience to the show.

\section{The F-word and the tradition of 'Blue' comedy}

Of course, the show's great delight for much of its audience is its vulgarity, especially in its repeated used of the F-word. The UK's long tradition of 'blue' comedy has, and continues to have mass appeal as it celebrates notions of 'togetherness through offensiveness' (Medhurst 2007: 187), where the delights of profanity and vulgar sexuality afford its predominantly working 
class audiences a sense of belonging to their own vibrant culture. Of course, enjoying profanity (and availing of its use) is not the sole province of one class over another. This acceptance across the variable class mix of its audience is central to the wider appeal of the show.

And the F-bombing comes fast and thick because O'Carroll knows his key audience; those same middle- aged women that Mrs Brown ably impersonates. Again, in the absence of research on specific audience data about the show, speculation here must of necessity be anecdotal. However contact with my own mother (78, and an avid fan) and others in the 50+ age grouping, illustrated that Mrs Brown's profanity produces a double 'hit' of comedy; delight in the joke itself as delivered, and an equal delight in the naughtiness experienced in enjoying what should be normally frowned upon, or, as per Freud's (1976) relief theory, unspoken and repressed.

The joy taken (by audience and performer) in regularly using the F-word for comic effect also connects with Bakhtin's (1984) notions of the lower body as a source of comedy. Saying $\mathrm{F}^{* * *}$ is the most basic expression of the sexual and in endlessly repeating it as part of 'ordinary' speech, Mrs Brown's Boys produces a carnival sense of pleasure for its audience that revels in its connectedness to all living things (Bakhtin 1984). In this sense, the profanity of the show illustrates Medhurst's essence of working class pleasure in 'blue' humour, with the show remaining at heart a 'comedy (that) is about the comforts of mass togetherness' (2007: 202), connecting the viewing (of all classes) to deep seated feelings of belonging - a powerful draw for any comedy audience.

\section{'It's a man in a $\mathrm{f}^{* * * * * i n g ~ d r e s s ' ~-~ b r e a k i n g ~ t h e ~}$ $4^{\text {th }}$ Wall}

O'Carroll readily admits he struggled with how best to transfer the success of Mrs Brown's Boys as a live theatrical event to the small screen until he hit upon his eureka moment,

we're not going to try and convince them they're in someone's living room, we're going to let them in on the joke, let them see we're filming a show... we're going to let them see the mistakes, the cameras, the lot. It will be brilliant (Beacom 2014: 274).

For O'Carroll and Mrs Brown's Boys, letting the audience 'in on the joke' (ibid.) is not just an occasional gimmick but is factored deeply into the fabric of the show. In episode after episode, the show declares it's artifice: from its behindthe-scenes opening sequence of the camera crew getting ready to film the waiting actors to fluffed lines or missed cues milked for their maximum comic effect (a late clearance of a camera during Dermot's wedding episode prompts the line, 'the man is here about the wedding video' (S1 Ep 5, Mammy of the Groom 2011). O'Carroll even 'outs' his own drag persona after a particularly sentimental mother-son moment that draws an equally sentimental 'aww' from the audience, by dismissively reminding them that, 'it's a man in a fucking dress!' (Mrs Brown's Boys S1 Ep 1, The Mammy 2011).

Unlikely as Mrs Brown's Boys may be as a source of postmodernist deconstruction, O'Carroll taps directly into a public highly aware of the world as a media environment. Wagg (1998) notes that feeding this awareness generates laughter by ingratiating oneself with the audience. O'Carroll may be letting them in on the gag, but it's a gag they were already keenly aware of, and by acknowledging it, he also acknowledges their sophisticated understanding of how popular culture (in this case the TV sitcom) works. This then is sitcom that regularly flatters the intelligence of its audience - and they can't get enough of it. Hence, in Supermammy, a highly contrived plot that sees Mrs Brown under the impression her kids are trying to be rid of her is knowingly sent-up by O'Carroll,

Mrs Brown: I thought you were going to put me in a home?

Dermot: Why would you think that?

Mrs Brown: It's in the script.

(Mrs Brown's Boys S2 Ep 5 2012)

The pay-off here gets a huge laugh, as both O'Carroll and the audience, not only poke fun at 
the contrived nature of an incredulous plot (her misunderstanding exists solely to drive a number of comic moments in the show), but also at the false nature of sitcom narrative itself.

Breaking the fourth wall in this manner also operates to bond the audience to the Browns during the fictional family's celebratory moments. A typical example is evidenced by the bringing on of the now 'married' Dermot and Maria during the shows credits, to shower them with confetti and enable the audience to witness the off-screen wedding that they'd been excluded from during the episode (Mrs Brown's Boys S1 Ep 6, Mammy of the Groom 2011). The Dermot and Maria's 'afters' and scenes like the standalone sing-a-longs that end each series (with the cast performing dances routines and Karaokestyle numbers for studio audience), connect the viewers to a 'meta'-Brown family that, for its dedicated fans at least, existed before its sitcom incarnation, and continues to exist outside the TV brand that is Mrs Brown's Boys. This linkage is undoubtedly strengthened by the real life family connections within the cast itself, with O'Carroll's wife, sister, son and daughter respectively playing his sitcom daughter, Cathy, best friend, Winnie, likeable wide-boy Buster Brady and daughter-in-law, Maria. This forges a vibrant emotional connection to the audience that actively contributes to its huge success. Medhurst's (2007) claim that all comedy functions on ideas of exclusion and difference (being 'inside' and 'outside' the joke) is clearly in operation here. For Mrs Brown's Boys breaking the fourth wall shifts the audience across barriers, from outside viewers of a comedy machine in operation to inside, active participants in completing the gag with their laughter. In the end, the enormous fun that Mrs Brown's Boys has with deconstructing that fourth wall, affords the audience another identity, one that values them as equals in mining the comedy of the show.

\section{Conclusion}

Mrs Brown's Boys, a show dismissed as 'a festival of wrongness' (Dent 2012), derived from "lazy end-of-the-pier trash rooted in the 1970's" (English 2011), engages in a complex interaction of discourses, of sexuality and the sitcom production process itself to capture and maintain it audiences affection and loyalty. Morreale insightfully notes that to laugh with someone is to live with them, to 'share a form of life with him (sic)' (1983 cited in Mills 2005: 9). In this short time spent with Mrs Brown and her brood, the show reveals itself as a 'form of life'(ibid.) that connects to the deepest wants of its audience and their most trivial sense of tomfoolery, often simultaneously,

Winnie: Agnes, do you ever miss the humptyhumpty thing?

Mrs Brown: What's to feckin' miss? The smell of Guinness and chips being breathed all over you? His chin like feckin' sandpaper, taking advantage of me whenever he liked. He'd come in and dive on me. And all I could do was lie there, and try to keep my place in the book.

(Mrs Brown's Boys S2 Ep 2 Mammy's Coming 2012)

Finally, its popularity perhaps derives from the comic power of speaking truths, about the raucous and joyous needs of post-sexual female desire, the comforts of authenticity in a media drenched world of 'smart' comedy, even about loveless sex and lives spoiled by drink and the imperfect world we all inhabit. At root, popular comedy always finds itself engaged in 'a discourse of daily survival' (Medhurst 2007: 202), lightening our collective load and offering the vibrant joys of community. In the end, the 'man in a $\mathrm{f}^{* * * i n g}$ dress' delivers communality and belonging in abundance to its appreciative audience, F-bombing us into exuberant laughter in the process.

\section{Works Cited}

Bakhtin, M. 1984. Rabelais and His World. Indiana: Indiana University Press.

Beacom, B. 2013. "Brendan O'Carroll's comic creation is generating Diana-like levels of public affection. Why has the nation taken Mrs Brown to its bosom?" The Big Issue, Ireland (Online). 27 September. Available from: http://www.bigissue.com/features/3055/mrs-brown-peoples-princess (Accessed: 30 July 2014) 
Dent, G. 2012. “Grace Dent on TV: Mrs Brown's Boys, BBC 1”. The Independent, United Kingdom (Online), 29 December. Available from: http://www.independent.co.uk/arts-entertainment/tv/reviews/grace-dent-on-tvmrs-browns-boys-bbc1-8432020.html (Accessed: 30 July 2014)

English, P. 2011. "Time travelling back to the 70's with Mrs Brown was an unpleasant experience." The Daily Record Blog. (Online) 24 February. Available from: - (Accessed: 30 August 2014)

Friedman, S., Mills, B., Phillips, T. 2011. Editors Introduction: Foregrounding the Comedy Audience. Participations Journal of Audience and Receptions Studies.8(2), pp.120-25.

Freud, S. 1976. Jokes and their Relation to the Unconscious. Pelican Freud Library, volume 6. London: Penguin.

Langley, W. 2014. "Mrs Brown's Boys: a show of two fingers to the critics”. The Telegraph (Online), 5 January.

Available from: http://www.telegraph.co.uk/culture/tvandradio/10548985/mrs-browns-boys-brendan-ocarrollbbc-comedy-christmas.html.

Medhurst, A. 2007. A National Joke: popular comedy and English cultural identities. London, New York: Routledge.

Mills, B. 2005.Television Sitcom. London: BFI Palgrave Macmillan.

Porter, L. 1998. "Tarts, Tampons and Tyrants: women and representation in British comedy." Wagg, S (ed). Because I Tell A Joke Or Two; comedy, politics and social difference. London, New York: Routledge. pp. 65-93.

The fancarpet. 2011. Interview: Brendan O'Carroll, Mrs Brown's Boys (Online). Available from: https://www.youtube.com/watch?v=uL971nrE3f8. (Accessed: 20 July 2014).

Wagg, S. 1998. “AAt Ease Corporal: social class and the situation comedy in British television, from the 1950's to the 1990's". IN: IN: Wagg, S (ed). Because I Tell A Joke Or Two; comedy, politics and social difference. London, New York: Routledge. pp. 1-31.

\section{Television/Filmography}

Bread 1986-91. BBC 1 (Television).

Catastrophe 2015 ongoing.Channel Four (Television).

Curb Your Enthusiasm 1999 ongoing. HBO (Television).

London Irish 2015.Channel Four (Television).

Married with Children 1987-97. Fox (Television).

Mrs Brown's Boys (Series 1, episode 1, The Mammy) 2011.RTE 1/BBC 1.(Television) 1 January, 10.00 pm.

Mrs Brown's Boys (Series 1, episode 5, Mammy of the Groom) 2011.RTE 1/BBC 1.(Television) 29 January, $10.00 \mathrm{pm}$.

Mrs Brown's Boys (Series 2, episode 1, Mammy Pulls It Off ) 2011. RTE 1/BBC 1.(Television) 31 December, $10.00 \mathrm{pm}$.

Mrs Brown's Boys (Series 2, episode 2, Mammy's Coming) 2012. RTE 1/BBC 1.(Television) 7 January, 10.00 pm.

Mrs Brown's Boys (Series 2, episode 4, Supermammy) 2012.RTE 1/BBC 1 (Television) 23 January, 10.00 pm.

My Family 2000-11. BBC 1 (Television)

Outnumbered 2007 ongoing. BBC 1 (Television)

Only Fools and Horses 1981-2003. BBC 1 (Television).

The Office 2001-3. BBC 2. (Television)

The Royle Family 1998-2012.BBC 1 (Television).

John Fagan is a lecturer in screenwriting and TV production, TV comedy and soap opera writer (credits include RTE's Nighthawks, Fair City and IFTA nominated short film Mir Friends). He is currently developing historical sitcom, Amazing Gracey about Ireland's Pirate Queen, Grace O'Malley, with Big Mountain Productions. 
The Irreducible Difference of the Other (Vivienne Dick 2013)

Eileen Leahy

Vivienne Dick's 2013 film The Irreducible Difference of the Other is a feminist work that critiques and destabilises the dominant (male) paradigm. Its weaving together of disparate sounds and images posits our interrelatedness as humans and challenges the prevailing understanding of relationships in terms of power, where one group or individual affirms themselves through dominating another. The film's myriad juxtapositions of discordant visual and aural filmic styles broaches questions about being human in a world directed towards war, terror and consumption and, in posing such questions, creates an idea of being human as a relationship across boundaries of difference and otherness. Irreducible... therefore provides an interesting addition to a body of feminist film, as well as to experimental and artist cinema more generally, which is worthy of analysis.

Vivienne Dick is best known as a leading light of the 1970s No Wave film movement in New York, which brought avant-garde experimental film into bars and clubs, screening trash Super 8 short films alongside punk bands and performances. She moved back to Ireland in the early 1980s then to London in the mid 80s where she was actively involved in the London Filmmakers Co-op. She has lived in Ireland, teaching and making films since the mid1990s.Dick's background in the No Wave scene is relevant to an understanding of her latest film because, although it is a very different style and form of film than her earlier New York shorts, there are a number of distinct references to that earlier work within Irreducible... Indeed, a showing of her No Wave short Super 8 works has preceded almost all of the screenings of this latest film. For example, She Had Her Gun All Ready (1978) was screened before Irreducible... at the
London Short Film Festival, the Feminist Film Festival in Dublin and at Indie Cork Film Festival. Lux Scotland has recently shown Dick's Staten Island (1978) and her Irish film Visibility: Moderate (1981) before it's screening of Irreducible... Thus The Irreducible Difference of the Other seems to be always directly linked to her earlier work in its exhibition contexts. There are also connections in the text itself, with references to the No Wave aesthetic in some of the audio (the performed-sound sequence by Suzanne Walsh which focuses on a close-up of her mouth at a microphone), the party sequences in which a bright red colour dominates, and the interview sequences, for example. This linking across time to an earlier period in history feeds into Irreducible...'s central theme of relatedness and interconnection. It also speaks to a concern with film form.

The 27-minute experimental documentary is packed with such a wide variety of shooting styles, locations and audioforms a denselylayered overall effect where no one approach dominates. This is achieved by careful editing with a very tight structure and rhythm echoed in both audio and visual repetitions. At a question and answer session after the screening at the August 2014Feminist Film Festival in Dublin, Dick referred to this film as a patchwork, a metaphor which helps unravel the film's complex composition. The formal devices establish relationships between and across discordant elements. For example, an overhead shot of a Cairo street introduces an interview with a roofgardener about weeding, before cutting to the diminutive figure of actress Olwyn Fouéré walking across a wide and very formally composed shot of a landscape in the west of Ireland. These scenes contrast sharply in shooting-

ISSN 1699-311X 
style, content and audio yet a relationship is established between them not just through the editing but through minute details that pepper the entire film. The fleeting glimpse of a red table surrounded by chairs outside a café in the overhead street scene, for example, hits a note that is repeated in the table and chairs on the rooftop garden terrace, in the red jumper of the gardener who kneels on the ground and whose pose is mirrored in the figure of Fouéré, shot from overhead, kneeling to drink water from a stream and again in the barely distinguishable red of the sculptor's dust-laden hat as she bends over her work. The entire film is suffused with such rhythmic repeats, not just visually but also in its complex and accomplished, sound design. The whole is made up of these various disconnected elements to create an impression that can only be comprehended from a distance, just as the repeat pattern of a patchwork quilt can only be understood by taking the focus away from the intricate detail to view the whole as one piece.

In this way the film connects dramatist Antonin Artaud to Russian poet Anna Akhmatova, both performed by Olwen Fouéré, and in turn related through filmic devices to a broad range of settings, locations and ideas. The Arab Spring, is conjured, for instance, and repeated in Anti-War street marches in Galway and Dublin, and connected to trash culture as a trio of glamorous young women gather before a night out in Dublin. Or a wedding party becomes a fancy dress carnival that collapses into a confused bride turning up at the Occupy Dame Street protest, a scene that in turn is mirrored by the poet standing in a rural landscape or collapsing into water. Sculpting conjugates the natural elements of fire and air and relates them to earth and water on an urban rooftop before they dissolve in a riot of street protest or nightclub carnival: we can't be sure which. This juxtaposition of opposing ideas, styles and formats becomes a cacophony within which the "other" becomes indistinguishable from the whole. In this way, the film disrupts documentary norms that facilitate our recognition of who we are through identifying an "other". Irreducible... instead invites us to grasp at a sense of "difference" or "otherness" as a relationship, rather than an opposition or antagonism.
It achieves this by presenting each as part of a richly textured whole, a whole that can only include each minute and differentiated element.

As Maeve Connolly (2003: 36-7) and Donal Foreman (2008: 249) point out Dick's work has, by and large, been excluded from discussions of Irish cinema. It is worth noting that, although she has been concerned with specifically Irish themes across a body of work (Connolly 2003: 36-7), Dick is more interested in crossing boundaries of national identity than in helping to construct them. The Irreducible Difference of the Other invokes Irish questions and concerns; it draws heavily on a tradition of the west of Ireland landscape as a primary source and of the relation of an urban culture to this tradition, for example. However, the main overall thrust of the film is to break down boundaries of Irishness as an identity, so that the figures in this Irish landscape, Antonin Artaud, the French avant-garde dramatist, and Anna Akhmatova, the Russian poet, both played or "channeled" by Breton-Irish actress Olwen Fouéré, challenge traditions of a wild, native, countryside as a basis for bounding Irishness by bringing in other nations and formations. This is further emphasised in audio for these landscape sequences where, for example, the music soundtrack might blend Eastern-sounding instruments with traditional Irish melodies or lines of poetic narration that are whispered, played backwards or otherwise distorted. The filming style, editing and audio blur the distinctions between the various urban settings and street protests, so that all merge into one global protest. Segments such as the touristic portrayal of the Egyptian Pyramids, whose amateur-style footage accentuates tour-guides and tour buses surrounding the site, fragment location as a filmic device while challenging notions of national heritage. These are just some examples of this film's destabilising of ideas about nation, place and identity, among a myriad of devices the film uses to upturn such fixities and connect cultures and identities across and between temporal and spatial boundaries.

Thus The Irreducible Difference of the Other constructs links between and across identities, selves and others. This film breaks down the bounding potential of culture by highlighting, not 
so much our commonality as humans, but that difference and otherness are indispensable elements without which the whole cannot exist. In this way it resists conforming to a national cinema or such notions as cultural distinction and $\mathrm{sp}_{1}$ the connectedness and interrelatedness of culture boundaries and borders.

\section{Works Cited}

Connolly, Maeve. 2003. "Excluded by the Nature of Things? Irish Cinema and Artist's Film." Circa 106. Winter: 33-39.

Foreman, Donal. 2008. "Experimental Conversations (2006): Ourselves Connected?” Estudios Irlandeses 3: $248-251$.

The Irreducible Difference of the Other (2013)

Directed and produced by Vivienne Dick

Editing by Connie Farrell

Featuring Olwen Fouéré

Eileen Leahy is an independent researcher who focuses on Irish cinema, community filmmaking and alternative cinemas. She completed a Ph.D, researching community filmmaking in Ireland, at the Department of Film Studies at Trinity College in Dublin in 2014. 
An Bronntanas [The Gift] (Tom Collins 2014)

Ruth Lysaght

Tom Collins has been an active force in Irish film-making for decades, having been involved in founding the Derry Film and Video Collective in 1984, and working as camera operator on the controversial documentary Mother Ireland (Harkin 1986). He has produced or directed many well-received documentaries, and in 2007 directed the bilingual feature about a group of Conamara immigrants to London, Kings (2007) which like An Bronntanas, was nominated as the Irish entry for 'Best Foreign Language Film' at the Academy Awards. ${ }^{1}$ This is an impressive record: given the challenges in making featurelength drama in Irish, it is unsurprising that only a handful of original features in the Irish language exist. ${ }^{2}$

Written by Collins, Joe Byrne, Paul Walker and Eoin McNamee, the story tells of the personal, familial and community fallout that ensues when the main character, reformed alcoholic and recently returned emigrant $\mathrm{JJ}$ Magill (Dara Devaney/ Darach Ó Dubháin), chooses the darker side. The story's central themes include filial loyalty, where the doughty Carmel (Charlotte Bradley) impels her younger son to take over his late father's struggling business despite his brighter prospects across the

1. Kings was very successful in terms of awards, winning the Gold Torc at the 2008 Celtic Film and Media Awards; a Special Commendation at Prix Europa Best Drama 2008; Best Cinematography Award at the Hamptons Film Festival 2008; Best Film at the Westchester Film Festival 2008 and a Special Commendation Foyle Film Festival 2008. Collins also won the Director's Guild of America / Ireland New Finders Award in 2007.

2. Later in 2015, the feature animation Song of the Sea (Moore 2014) is due to be released in an Irish and an English version (Clarke 2015). the Atlantic, and romantic love, where the feisty Róisín (Michelle Beamish) chooses the better of the two brothers and manages to keep a blind eye turned to their increasingly frantic cover-ups. Community is personified in the factory workers, who rely on one entrepreneur to keep their town working, and the Irish-American Garda Seán Óg (John Finn), whose courteous manner belies distress at his detective son (Owen McDonnell) Fiachra's cruelty. First broadcast as a five-part television series in October-November 2014, An Bronntanas was very successful with its core audience, (a survey by the audience panel Fios Físe showed $60 \%$ to be 'very satisfied' with the series) and the wider Irish public (TAM ratings for the first four episodes reached 340,000), making the thriller one of the most popular indigenous dramas so far on TG4. Similarly, the feature film 'cut' attracted a capacity crowd at the Galway Fleadh in July 2014 (Butler 2014).

This was not the first time that ROSG, a small Conamara independent production company cofounded by Ciarán Ó Cofaigh and Robert Quinn, sought to express a noir vision in its drama. Since the beginning of the short film schemes organised by TG4 and the Irish Film Board/ FilmBase, ROSG's presence has been consistent, with Cosa Nite [Clean Getaway] (1998) and An Leabhar [The Book] (2000), both nominated as 'best short' at the 1999 and 2002 IFTAs respectively (Lysaght, 2004). ${ }^{3}$ Their 2010 series/ feature adaptation $\mathrm{Na}$ Cloigne [The Heads], ventures into supernatural territory. ${ }^{4}$ Although

3. Cosa Nite tells of foul play in the bog, adultery and three attempts at murder, and An Leabhar follows a student who is offered a new career by a band of professional assassins. Quinn won the prize for best first film (An Leabhar) at the Celtic Media Festival, 2001. 
ROSG is also involved in documentary and animation, the dark aesthetic of their fictional offerings continued into longer productions such as the ambitious feature Cré na Cille (2007), a visually rich adaptation of Máirtín Ó Cadhain's eponymous modernist novel.

An Bronntanas was originally designed as a six-part television series, but due to funding difficulties, the decision was made to reduce this to five-parts with a companion feature film version also produced for festival screening (Ó Cofaigh 2014). In the vein of Celtic noir, whose atmosphere is influenced in equal part by recent Nordic noir TV drama and by the darker side of Irish rural society, An Bronntanas engages with big moral dilemmas faced by ordinary people. The storyline follows the twists and turns that ensue when a volunteer lifeboat crew decides to cover up an unexpected drugs find - and a murder - for their own gain. Dealing with characters on and beyond the margins (fish factory employees in danger of being downsized, Polish visitors, alcoholics and returned emigrants - not to mention Irish-speakers), the drama overturns older screen images of the romantic west. Filmed all over Conamara, An Bronntanas was four years in the planning, with action, gun, explosions and night-time boat rescue storm scenes, ${ }^{5}$ making it a very ambitious project for the time and finances allowed.

There is an air of mystery throughout the early sequences, as we cannot identify certain key figures (e.g. the murderer of Anna Terescova (Eimear O'Grady)) and we do not have reliable access to the motivations or interests of several characters. JJ is similarly enigmatic, showing little of his almost certain emotional struggle as

4. Na Cloigne won 'Best original music' IFTAs 2011, 'best drama series' at the Celtic Media Festival (2011), 'TV drama of the year' at an tOireachtas 2011 (an tOireachtas 2012). Darach Ó Dubháin (Dara Devaney) also won 'best actor' at the Oireachtas.

5. "We spent a good year and a half trying to figure out how to do those scenes so we had it very well figured out between ourselves, the DOP Cian de Buitléar and the FX team from Team FX. But of course the days we were shooting the storm scenes the weather was lovely and calm so we had a lot of work to create a storm!" (Ó Cofaigh 2014) he returns from Canada for his father's funeral, learns of his mother's plans and that his brother Macdara (Pól Ó Gríofa) has descended further into alcoholism. JJ veers between physical and emotional absence and presence, as he gradually finds a place to stand. He appears to be holding himself together, rarely allowing anxiety to surface. During the dramatic sea rescue attempt, $\mathrm{JJ}$ ends up overboard, physically immersed in the Atlantic, between two worlds. His eventual decision to keep quiet about the crew's discovery seems to be due as much to a strong wish to come 'home' and to re-belong as to any question of greed.

As in Kings, we see the story of the emigrant/immigrant, from inside and without, as Irish, American and Polish characters deal with financial struggles, moral responsibility and the negation or recovery of links to their family and home community. There are many strong resonances with contemporary Irish life, such as the worry of the single mother (Siobhán O'Kelly) losing her job as the factory downsizes, interactions between Polish and Irish workers, drink being the response to social and geographic isolation and the complex relationship between the forces of law and order with the rural community (as examined recently the documentary The Pipe (Ó Domhnaill 2010)).

Whilst the sweeping landscapes of the west play host to car and bike chases, rocky islands contain fatal caves and the strong waves of the sea alternately conceal and reveal what is a double-edged 'gift' (An Bronntanas being the name of the boat containing the corpse and drugs), our attention is primarily focused on the characters' faces. Director of Photography Cian De Buitléir makes the most of his opportunities for broadening the setting, with poetic use of light and contrasting interior and exterior spaces - but the project ultimately remains more televisual than cinematic.

The story unfolds in a small Connacht town, with forays into Jakub's caravan, Carmel's kitchen and the bedroom of the B\&B where Anna was staying. The pub (in a neighbouring town) serves as a setting for an attempted drug sale and backroom torture, featuring one of the least developed characters in the person of an English dwarf drug-dealer. The fish factory, with its blues 
and whites, is the perfect foil for the darker colours of guilt and blood in the night, as $\mathrm{JJ}$ and Jakub attempt to dispose of another body.

As Ireland is situated between two important anglophone centres of high quality audio-visual production, the visibility (or audibility) of local fiction in Irish cannot be taken for granted. To attract audiences, An Bronntanas plays a double game, deploying generic conventions from international crime drama in a local setting with a mixture of Irish and international characters and actors and using a language which implies regional authenticity. The drama walks a tightrope between genres, cultures and languages, which makes the production all the more interesting:

we have achieved something in Irish that has never been done before on such a scale (Ó Cofaigh 2014).

The primary criterion for judging $A n$ Bronntanas has to be its visual and narrative force, as opposed to its language. However, as the Irish language is strongly present, and is not yet 'transparent' for most audience groups, it is useful to consider its effect as an additional layer of interpretation. In other words, the use of Irish (and Polish) in an environment where English is the dominant language creates a sort of imaginary opacity for many viewers, which may contribute to the creation of a certain atmosphere. Consider the air of exoticism enjoyed by recent subtitled 'noir' or detective series from Scandinavia, which have been very popular with Irish audiences. As Ó Cofaigh points out, series such as The Bridge or The Killing (broadcast on TG4) have made people more open to subtitles in fiction (Ó Cofaigh 2014). ${ }^{6}$ However, some critics still find the use of Irish in the context of a crime thriller difficult to accept (Kearns 2014).

We are currently at a threshold stage in the criticism of Irish-language productions gradually moving away from reflex reactions to

6. According to critic Pat Stacey, the use of Irish in An Bronntanas only adds to its market potential: "it has everything the BBC4 audience could want: murder, mystery, betrayal, corruption, guns, drugs, doublecrosses, plenty of exotic (for UK viewers) local flavour and, of course, subtitles" (Stacey 2014). early TG4 work, whose high standard pleasantly surprised English-speaking critics in "an rud is annamh is iontach" [what's rare is prized] mode. Instead of praising an Irish-language drama for its very existence (which unfortunately remains common), we are now entering a phase where the volume of previous productions is starting to provide enough of a critical backdrop by which to measure new work. Of course, it is too early yet not to take into account the presence and influence of the language on contemporary productions.

For ROSG, Irish is an integral part of the work from conception to production and is used normally as a means of communication. Their vision is to develop production and the language:

[no matter the genre] when it is done as Gaeilge it is always breaking new ground. I believe, whether I'm right or wrong, that we can make a positive difference on behalf of the Irish language. There is always an added dimension in proving that strong, relevant TV and Film can be produced as Gaeilge (Ó Cofaigh 2014)

This approach is very different to that taken by non-Irish-speaking production houses, where the language is used in a more self-conscious manner. ${ }^{7}$ In ROSG productions, Irish is "a natural part of the landscape and culture" (Crosson 2011). In an interview with Seán Tadhg Ó Gairbhí for the news website Tuairisc, Ó Cofaigh underlines this idea:

níl aon phointe ann go bhfuil Gaeilge á labhairt ag na carachtair, just tarlaíonn sé go bhfuil" [There's no particular reason that the characters speak Irish - they just happen to speak it] (Ó Cofaigh dans “Agallamh faoi An Bronntanas” 2014).

Although the language can be said to be less 'visible' for an audience of fluent speakers in terms of narrative, it is hugely important in terms of production process.

Much has been made of the appearance in $A n$ Bronntanas of the American actor John Finn, known to audiences mainly for his role as Lt. John Stillman in the TV series Cold Case (he also

7. In other words, Irish is used by people who would not usually speak it, which makes it appear more salient or 'forced'. 
featured in a TG4 joint promo for Ros na Rún and Cold Case in 2005). Finn's presence certainly helped with the profile of the drama, and it is important to note that his participation in the project was largely due to good will: "I did it for next to nothing but I would have done it for nothing! ... It was a wonderful thing for me"(Finn 2014b). Finn, who has been learning Irish for some years, remarks positively on the atmosphere on set: "I think the best part was being able to work with a crew who used the language in a practical sense" (Finn 2014b). Such gestures have been a feature of Irish-language film production for several decades. It is encouraging to see the support that actors and crew have for the language, but it is dangerous to assume that the industry can grow and develop if professionals are not paid properly for their craft.

Although Finn is the most prominent 'star' in An Bronntanas, Janusz Sheagall in the more demanding role of Jakub, is stronger in terms of screen domination. His performance is subtle and finely balanced, garnering positive reviews from Film Ireland (Butler 2014) and Film Flixx (Kearns 2014). Some of the other characters' roles are less than fleshed out - we can see that a sixth episode may have helped to fill in some of the missing pieces. Less background and motivation is provided for the female characters in general, and the baddies tread an uneasy line between viciousness and just not funny enough.

There are several successful scenes where tension is conveyed by masterly photography, editing, music and performance: clear examples are the attack on Anna in the boat and her struggle to communicate her situation by phone, and the storm rescue of JJ. Another interesting moment which plays with linguistic and cultural difference to excellent narrative effect is the scene where Jakub's Polish superior is mistranslated in virtuoso low-key style at the coffin of his colleague, and the kindly Seán Óg takes it all at face value.
Violence is treated alternately in realistic and comic mode, and the latter does not always work. There are genuinely unpleasant scenes, such as the torture of Macdara by Fiachra in a confined setting, but also some ridiculous ones, where the English dwarf and his local sidekick seek revenge with a hurley. Another scene which stretches credulity (not to mention gore-viewing capacity) is one where car keys are being sought in a vat of human and fish entrails - surely somebody could have hotwired the jeep!

It is important to note the ambition and reach of the drama, evident in the many successful sequences, but also in a few 'nearly there' scenes, which demonstrate the potential for future fiction productions from this team. An example of a scene which almost achieves its goal is the father and son stand-off/ sacrifice in the cave towards the close of the story. The pace is just a little too fast to properly honour the electricity and selfrealisation of the moment, and it is a pity to gloss over what could have been much more powerful. ${ }^{8}$

An Bronntanas is an ambitiously realised and often genuinely tense tale of how people have to live with the consequences of their decisions, first in their immediate circle and beyond into society. The interplay of Irish, English and Polish adds another layer to the challenge of figuring out who to trust. A majority of strong performances, credible special effects and sensitive musical choices make this a drama worth watching.

\footnotetext{
8. Of course, some such gaps are due to the constraints of the format, rather than conscious artistic choices: "we shot the series with the structure of the film in mind and even though there is obviously less in the film than the series, a lot less time and by default less depth to it, it still works really well as a stand-alone piece" (Ó Cofaigh 2014).
}

\section{Works Cited}

Agallamh faoi An Bronntanas. 2014. October 22. Retrieved from http://tuairisc.ie/fisean-agallamh-faoian-bronntanas/ 
Agallamh faoi An Bronntanas. 2014. October 22. Retrieved from http://tuairisc.ie/fisean-agallamh-faoian-bronntanas/

Butler, C. 2014. July 15. "An Bronntanas - Review of Irish Film at the Galway Film Fleadh | Film Ireland". Film Ireland. Retrieved from http://filmireland.net/2014/07/15/an-bronntanas-review-ofirish-film-at-the-galway-film-fleadh/

Celtic Media Festival. 2011. "Past winners 2008 - present - Celtic Media Festival". Retrieved December 15, 2014, from http://www.celticmediafestival.co.uk/past-winners/2

Clarke, D. 2015. January 15. “Oscars 2015: Tomm Moore's Song of the Sea gets nod”. The Irish Times. Retrieved from http://www.irishtimes.com/culture/film/oscars-2015-tomm-moore-s-song-of-thesea-gets-nod-1.2067091

Crosson, Séan. 2011. "Na Cloigne (2010) ”. Estudios Irlandeses 6: 202-204.

Finn, J. 2014a. October 23. New York actor, John Finn learns Irish for new TG4 role! | Today | RTÉ One YouTube. Retrieved from https://www.youtube.com/watch?v=kLjsmArEN6E

Finn, J. 2014b. October 23. "Interview: US star John Finn talks TG4's 5-part thriller An Bronntanas Scannain". Retrieved from http://www.scannain.com/interview/an-bronntanas-john-finn\#

Harkin, Margo. 1986. Mother Ireland.

Irish Film Festival, Boston. 2015. \#irishfilmfest15 | Thursday, March 19 - Sunday, March 22, 2015. Retrieved March 6, 2015, from http://www.irishfilmfestival.com/

Kearns, J. 2014. September 18. "An Bronntanas Review - FilmFixx”. Retrieved March 4, 2015, from http://filmfixx.com/bronntanas-review/

Lysaght, Ruth. 2004. "Súil Eile, Dúil Nua (Another Perspective, a New Desire): Short Films in the Irish Language Since the Advent of TG4". In N. Alexander, S. Murphy, \& A. Oakman (Eds.), To the Other Shore: cross-currents in Irish and Scottish studies (pp. 85-94). Belfast: Cló Ollscoil na Banríona.

. 2013. "Dramatising Identity on Irish Language Television: Aifric (TG4)". Estudios Irlandeses 8: 43-52.

. (forthcoming). "Sin scéal eile - contemporary screen adaptations of Irish stories for TG4".

L'Irlande en séries - Irish TV Series Conference.

Moore, T. 2014. Song of the Sea.

Ní Bhrádaigh, E. 2008. "An Léargas Fiontraíochta”. In E. M. T. O’Connell, J. Walsh, \& G. Denvir (Eds.), TG4 @ 10: deich mbliana de TG4/ ten years of TG4 (pp. 137-154). Indreabhán: Cló IarChonnachta.

Northern Ireland Screen. 2014. November 20. "Impressive viewing figures revealed for ILBF funded An Bronntanas". Retrieved December 10, 2014, from http://www.northernirelandscreen.co.uk/news/3770/impressive-viewing-figures-revealed-for-ilbffunded-an-bronntanas.aspx

Ó Cofaigh, C. 2014. October 22. IFTN Speaks to "An Bronntanas” Producer Ciarán Ó Cofaigh. Retrieved from http://www.iftn.ie/news/?act1=record\&only=1\&aid=73\&rid=4287665\&tpl=archnews\&force=1

Ó Domhnaill, R. 2010. The Pipe. documentary.

Quinn, D. 2009. Athshamhlú na teanga i scannánaíocht na Gaeilge: Ros na Rún, an Gearrscannánaíocht, Aifric, Kings agus The Running Mate (Unpublished togra taighde - final year undergraduate research project). NUI Galway. 2007. Cré na Cille.

ROSG. (n.d.). Retrieved August 5, 2010, from http://www.rosg.ie/en/ 
Stacey, P. 2014. October 23. An Bronntanas - TG4's cracking new thriller as gaeilge - Independent.ie. The Irish Independent. Retrieved from http://www.independent.ie/entertainment/television/tvreviews/an-bronntanas-tg4s-cracking-new-thriller-as-gaeilge-30686695.html an tOireachtas. 2012. Gradaim Chumarsáide an Oireachtais 2012. Retrieved December 10, 2014, from http://www.antoireachtas.ie/foirm/foirmainmniuchain2.php?PHPSESSID=555419c729437395c410fe254079c106

Ruth Lysaght lectures at the Universite de Bretagne Occidentale (France). She was scriptwriter for the TG4 documentary series on Irish cinema Muide Éire (Underground Films/Odyssey Media, 2011). 


\title{
Out of Here and What Richard Did: Listlessness \& Inarticulacy in the Young Irish Population
}

\author{
Deirdre Molumby
}

In recent years, Ireland has seen a major shift in confidence and self-value as the growth generated by the Celtic Tiger collapsed in the wake of the financial crisis. Recent Irish cinema has responded to this through the prism of young Irish people's experience of these events. Three years ago, director Lenny Abrahamson released his third feature, the critically-acclaimed ${ }^{1}$ and award-winning $^{2}$ What Richard Did, a representation of the young, affluent post-Celtic Tiger generation, albeit with a dark underbelly. In 2014, Donal Foreman's debut feature Out of Here was released, this time reflecting on the experiences of the young, lost generation of Ireland in the wake of the recession ${ }^{3}$ Out of Here tells the story of Ciarán (Fionn Walton) who, after a year of travelling abroad, reluctantly returns to his home in Dublin and struggles to reconnect with the city, his family and his friends.

Foreman has said that he was attracted to Out

1. The film received five out of five star reviews from RTE.ie and The Irish Times, was praised by the New York Times, and currently holds a 94\% approval rating on the rating based website Rotten Tomatoes.

2. The film won five awards at the Irish Film and Television Awards, including Best Director, Best Film and Best Script Film, as well as Best Film at the Dublin Film Critics Circle Awards and Best Film at the Istanbul International Film Festival.

3. A 2013 ESRI Report found that the youth unemployment rate increased, that labour force participation rates among those aged 15-24 declined, and that the rate of transition to employment for unemployed youths fell dramatically between 2006 and 2011. The results were concluded to be due to the impact of the recession (http://www.esri.ie/UserFiles/ publications/WP465/WP466.pdf, Published Sept 2013, accessed 6 Feb 2015). of Here by "the idea of using the vehicle of a character returning to the city after a year away as a means to explore Dublin, especially Dublin as it is for young people, from a fresh angle places he was once familiar with would now be estranged, so he has that double-sided relationship with the city." Piers McGrail, every shot and stylistic feature of the film feeds into this theme and the overall tone of the film. When Ciarán first arrives back at his house in Dublin, the shots taken through hallways and from outside of doorways create a sense of distance and strangeness in what should be a familiar place for Ciarán. Photographed by Piers McGrail, every shot and stylistic feature of the film feeds into this theme and the overall tone of the film. When Ciarán first arrives back at his house in Dublin, the shots taken through hallways and from outside of doorways create a sense of distance and strangeness in what should be a familiar place for Ciarán. There are a number of shots throughout the film of Ciarán simply walking around the city, reflecting his roving attitude and ambiguous feelings towards his return home. The film offers a mix of ugly and beautiful images, a city centre rubbish bin contrasts with the hidden spot that Ciarán is brought to by his friend, John (Dean Kavanagh). These mirror how Ciarán is now viewing Dublin in alternately familiar, new, and surprising ways. Foreman refuses to get too sentimental about Dublin but still gives the locations a sense of

\footnotetext{
4. Donal Foreman. "IFTN Interviews Donal Foreman, Director of Out of Here" http://iftn.ie/?act $1=$ record \&aid $=73 \&$ rid $=4287733 \&$ $\mathrm{sr}=1 \&$ only=1\&hl=donal+foreman \&tpl=archnews Words by Deirdre Molumby, Published 7 November 2014, Accessed 6 February 2015
} 
character and liveliness, whether it's a mower tractor crossing an idyllic park scene, a jogger passing by as Ciarán looks out across Dublin bay, or even a seagull idly swimming past Ciarán as he himself takes a swim.

Fionn Walton, who stars as Ciarán (having previously appeared opposite Jack Reynor in What Richard Did), has said of his character in Out of Here: "He's a reasonably ordinary young Irish man, so hopefully he'll be relatable for the majority of audiences. In his early twenties, he's on the cusp between adolescence and manhood, and he's finding the transition quite difficult to navigate. He's in the all too familiar situation of having expected that he might by now have some degree of clarity of what direction he'd like to take in life, yet feeling dismayed, adrift and conflicted about his future. He's certainly restless and very frustrated, and there's a great ambivalence to how he feels about his native city, which the film explores... I could certainly identify with the kind of listlessness he experiences, the difficulty he has in motivating himself, and the uncertainty he feels in relation to his future." 5

It is through Ciarán's perspective that we follow the events of the film, but listlessness is also evident in the other young characters. His friends work in call centres or in short-term apprenticeships and, like him, most of them still reside at home, their reliance on cycling or public transport to get around a signifier of their limited financial means. His younger sister is planning on travelling for the year with a friend but they haven't "sorted out exact jobs yet." Jobless and lacking in motivation, the adolescents revel in drinking and socialising rather than worrying about the future, and are seemingly indifferent to it. The film presents a generation which, having completed formal education, is now confronted by a highly unpredictable future, lacking the predetermined pathways of earlier generations.

5. Fionn Walton, "IFTN Interviews Fionn Walton, Star of Out of Here", http://iftn.ie/?act1=record\&aid= $73 \& \mathrm{rid}=4287729 \& \mathrm{sr}=1 \&$ only $=1 \& \mathrm{hl}=\mathrm{donal}+$ foreman $\&$ tpl=archnews. Words by Deirdre Molumby, Published 6 Nov 2014, Accessed 6 Feb 2015.
Ciarán alone seems to exhibit frustration at this state of affairs: if other characters feel the same way they seem unable to express it.

Indeed, Out of Here represents the inarticulacy and incapacity of Irish young people to communicate their feelings effectively. ${ }^{6}$ Debbie Ging has identified Irish men as "variously troubled by verbal expression' as a recurring feature of recent Irish cinema including Garage (2007), Kings (2005) and Parked (2010). In the case of Out of Here, both the trauma of recession and the unpredictable course of adulthood have also rendered its young male characters unable to articulate their fears and disappointment. This theme is indicated from the very first scene in which Ciarán and a friend have a nonsensical conversation at the end of a staircase. It is hard to take the exchange completely seriously given the two are intoxicated, laughing throughout the conversation, going from talking about 'fisting' to how they are best friends, and Ciarán makes sarcastic comments such as 'You smell delightful' as they hug. Ciarán also has a sarcastic exchange with Jess (Annabell Rickerby), his ex-girlfriend, and her new boyfriend at the cinema. When asked what he did while he was away, he jokes that he has actually been staying in his basement all this time.

The communication we see between the adolescents is based on humour, teasing and sarcasm. Conversations "curl and meander"7 rather than revealing emotions, which is probably why Ciarán is discouraged from articulating how he really feels about his return to Ireland. Asked how he feels about being back, he merely says "it's my scene anyway", which reveals little. He finds it difficult to express his feelings to Jess, who is much more open and says she was

6. See "Language, Loquaciousness and Silence" in Men and Masculinities in Irish Cinema (London: Palgrave, 2013).

7. Donald Clarke, "Out of Here review: a pictureperfect framing of a time and a place" http://www.irishtimes.com/culture/film/out-of-herereview-a-picture-perfect-framing-of-a-time-and-aplace-1.1990891. Published 6 November 2014, Accessed 20 February 2015. 
disappointed that he did not write to her. Even his apology for this turns into a joking "sorry for everything I ever did", which breaks the tension and allows them to evade the subject. The truth about why he came home, that he was robbed, not because he wanted to return, is told to a group of drama students he has only just met rather than to his friends. His confession - "Now, I'd fucking kill to walk down one of these streets and just not bump into, or not see anyone I know... and I'm sick of walking around this place and being reminded of shit that's over" - is told to people he will probably never see again. When he finally tells Jess he still has feelings for her, he can barely compose his words: "I like you, we should be together. I'm sad. I mean, if we can't, I mean you're the only..."

The adolescents of What Richard Did are from a very different background, inheritors of the 'boom' era rather than the 'bust'. It is worth noting that that film follows the younger age group of seventeen to eighteen year olds rather the twenty-something year olds of Out of Here, and thus the characters don't have the same pressures of "settling down and getting a job". Richard (Jack Reynor) and his friends are welleducated, cheerful characters with Richard as their 'golden-boy' - accomplished and adored by all his peers. Though they are more affluent, like the young people of Out of Here they lack a sense of direction. Richard says he wants to study full-time and play rugby but we never learn what he intends to become. His girlfriend Lara (Roisin Murphy) is also unsure of what she wants to work as, telling Richard's parents she will "just do Arts". In both films, the youths spend a great deal of screen time drinking and having 'craic.'

The Dublin setting shared by both films is also important. According to Frank Mort, the urban landscape evokes "fractured identities" for young men as the spaces and places of cities "thro[w] up new cultural personas." $" 8$

Although Richard tells his friends early on in the film that he "can talk to them about pretty

8. Frank Mort, "Boy's Own? Masculinity, Style and Popular Culture' in Male Order: Unwrapping Masculinity. Lawrence \& Wishart: London, 1988, p. 21 much anything", this turns out to be untrue as he becomes closed off and introvert when he and his friends accidentally kill an acquaintance, which marks the turning point of the film. When he confesses what he has done to his father, his father walks away from him. Instead of opening up to friends and family, Richard cries to himself and a particularly powerful scene in which Richard screams and thrashes about in anguish at what he has done captures the frustration of a generation that is unable to grasp or do anything about the unprecedented changes that adulthood and responsibility brings. Richard seemingly gets away with his crime, as he is shown attending college in the film's closing shots, but he no longer socialises and keeps to himself.

Although Richard comes from a very different context to Ciarán, both share traits of listlessness, inarticulacy and trauma. In Ciarán's case, the latter comes from a combination of "reverse cultural shock" in returning to Dublin as well as the impediments incurred by the financial crisis. While a society experiencing permanent crisis creates difficult if not intolerable conditions, Ciarán can be seen as particularly traumatised given he was part of a generation raised in more prosperous times. ${ }^{9}$ Richard experiences trauma as a result of murdering someone and having to lie about it. If Richard is a child of the Celtic Tiger, it may not be too much of a stretch to say that his lies and unacceptance of responsibility mirror those of the politicians and bankers of the era.

What is also refreshing in both films is that neither Abrahamson nor Foreman judge or, in Richard's case, punish the young men for the situation they find themselves in. This has been recognised by other critics: Debbie Ging has written that What Richard Did "is preoccupied with the moral crises experienced by the characters

9. One response to this social context which offers no future to young men has been the high incidence of suicide among young Irish males. Men under the age of 25 accounted for $18.7 \%$ of male suicides between 2007 and 2011. http://www.cso.ie/en/releasesand publications/er/ss/suicidestatistics2011/\#.VPmJr PmsXGY. Published 19 Sept 2014, Accessed 6 March 2015. 
after the event rather than with their motivations" 10 , while Gavin Burke, in his review of Out of Here, also recognises that "there's no pointed finger, no blame - this is just how it is."11 Though Ging assigns a degree of blame to Richard's father, who does not exercise paternal authority and instead helps his son "get away with it" ${ }^{12}$ it is a relief that, rather than assigning guilt, the audience is left to make up their own minds about what it means to judge a character, particularly when they are young and have not yet become responsible adults.

One could argue that the themes of listlessness and inarticulacy are not uniquely Irish but universal

10. Debbie Ging, "What Richard Did" in Estudios Irlandeses Issue 8, 2013, p.211

11. Gavin Burke. "Homecoming for Ciarán is a far from joyous experience", Mail on Sunday 02638878 , 11 September 2014, p.72

12. In her review of What Richard Did in Sight \& Sound, Hannah McGill points out that "The sole offer of help comes to Richard from his Danish father (Denmark helped to bail Ireland out with a $€ 400$ million bilateral loan in 2010)" (Vol. 23 Issue 2, February 2013, p.109) universal issues for young people. However, I have shown that what make these texts unique are their foundations in place and time. While What Richard Did contemplates the inability of the wealth generated by the Celtic Tiger to solve young people's problems (and in fact, arguably, led to a morality crisis as materialism and competitiveness replaced values such as selfsacrifice), in Out of Here the financial crisis has left the young generation jobless and freewheeling.

The final shot in Out of Here is glorious and celebratory, as Ciarán and his friends run naked into the sea until they are lost in the darkness, their delighted shouts lost in the distance and only the ocean waves heard as the credits roll. It would seem that the Great Recession has not quite crushed the spirit of the young people it left behind and that Ciarán has decided to live life for the moment. Although this resolution only really delays Ciarán's dilemma (and that of the Irish young people he represents), still, perhaps inaction is unavoidable. Irish youths may have no other choice except to emigrate or to wait for things in the country to get better. The only problem with this is it won't be long before they become the adults responsible for that change.

Deirdre Molumby is an MLitt in Film Studies candidate at Trinity College Dublin. 


\title{
A Poetics of Mental Illness: Patrick's Day (Terry McMahon 2014)
}

\author{
Barry Monahan
}

To immerse oneself in the world of Terry McMahon's Patrick's Day is to be challenged by a film written and directed according to the rules of the central treatise on the construction of narrative: Aristotle's Poetics. But McMahon's fidelity to the realm of necessity is neither heavyhanded nor explicit; rather, his aesthetic seems entirely faithful to, and respectful of, a piece that allows specific evolution of his characters. Everything about the film seeks to offer the audience a direct and unsensational depiction of its schizophrenic protagonist, Patrick Fitzgerald (Moe Dunford).

The story develops from the fraught and dysfunctional relationship between Patrick and his mother Maura one life-changing Patrick's Day when she takes him from his institutional home, as she does annually to celebrate his birthday. On this occasion, having become separated from her, he encounters Karen Prescott (Catherine Walker), who has been contemplating taking her own life for reasons that are not detailed. Without knowing anything of her situation but taken by her frankness, Patrick falls for Karen, who reciprocates his interest with some hesitation, and they subsequently consummate their feelings.

This new emotional connection develops tentatively over the course of the film, but disturbs the maternal-filial bond as Patrick's mother perceives it and she sets out to prevent the relationship with maniacal intensity. She attempts to separate the two by pushing Karen away - in spite of her knowing that Karen is now bearing Patrick's baby - and by pretending to Patrick, after a severe course of shock therapy, that Karen has never existed and is no more than a figment of his schizophrenic imagination. The narrative presents some of the most destructive elements of distorted and dysfunctional human relationships, and does not pull punches in requiring that we confront directly the issues. The film is handled so as not to get carried away emotionally, or facilitate easy access for its spectator into the story world, the characters, or their circumstances and motivations.

In an early scene, for example, when air hostess Karen first meets Patrick on the steps of the hotel in which they are staying, they have a conversation about their position as social "pariahs"; forced to smoke their cigarettes outside. Her address to him is delivered with a clipped turn-of-phrase that would not be out of place in a 1940s' film noir. Punctuated with phrases like: "That'll be your cue, kiddo ... light me up", as she offers him her cigarette, and the later flippant aside "Part of this town died the day they banned smoking in bars", her lines place her in an unreal, protected place where she uses clichéd demeanour to shield a deeper psychologically troubled situation. When he finally responds to her one-liners, she snidely quips: "So, it speaks", thus emphasizing the emotional distance still between them. McMahon maintains the taciturn tone of the exchange, and where we might otherwise expect a gradual thawing in their relationship or a softening of her brashness, neither occurs, and the scene concludes abruptly as she bursts his red balloon with her cigarette.

This tentative, unsentimental tone persists up to the moment they consummate their relationship. Outside her hotel room door, where typically we would expect a disingenuous hesitation, she confronts him - and his "motives" - with frank bluntness:

Karen: What're you waiting for, an invitation?

Patrick: I'm schizophrenic.

Karen: Aren't we all!

Karen's emotional directness, the cynical attitude of investigative cop, John Freeman (Philip Jackson) 
and the relentless, pathological Oedipal severity of Maura (Kerry Fox), will likely alienate many viewers. However, as they are presented to us, the very point seems to be that we can only come to an understanding of Patrick and his position of social marginalization by dis-relating with the characters that surround him. Thus, our point of view is gently aligned with Patrick's, a position that is visually communicated with cinematic intricacy.

Although the hospitalized protagonist, whom society has confined so that he is alienated as "contained insider" and we occupy a position of "privileged outsiders", McMahon reminds us in subtle ways that this situation can be easily overturned, and the inside/outside separation is based just as much on perception as it is in reality. One example of the film's constant asking us to question this received perspective on the mentally ill occurs early on. In the opening shots as Patrick wheels the stock trolley of convenience store between the shelves, spinning it around as he goes, it is we, the spectators, who are placed inside the "cage", looking out at him and the store. Later, before Patrick and Karen make love, it is he - not she - who is bathed in soft, intense light. The picture is slightly overexposed, and the image is softened in a way that renders Patrick's emotional state expressionistically, yet prevents Karen from being objectified and fetishized under his gaze. At another moment that aligns us with his thinking and his emotional situation, he runs her business card along the inside of the window of the room in the institution where he lives. The shot that frames this simple action, with the illustration of an airplane running up along the window is underscored by the slight, but again unmotivated, sound of a plane taking off. At Patrick's moment of imaginative escape, where he hears the jet engines, the viewer is granted access to his intimate thoughts.

This metaphorically weighted use of Karen's business card is one example of an objective correlation - the symbolic concrete manifestation of more abstract concepts (in this instance, as a signifier of Patrick's relationship with Karen) that McMahon uses to rich effect throughout the film. Others include the Ferris wheel (on which
Patrick gets stuck shortly having become separated from his mother at the beginning of the film), which neatly represents the cyclical Oedipal circumstance in which he is caught; his red balloon which Karen bursts, signifying her intervention into his situation; The Shining-like labyrinthine hotel corridors with their drab repetitious banality; and the use of vertical lines - such as those of the mirrors - that graphically match Patrick and Karen across a number of cuts, and serve to connect and unite them rather than split and separate them as individual "damaged" personalities. Significantly, this is reiterated visually, but for contradictory effect, to mark the sterility of his mother and the policeman's - John Freeman's - relationship and their failure to connect (across the divided pane of glass in the station).

Other moments are marked by oppositional symmetries and asymmetries, such as his mother's obsessive control over him (marked by her annual addition of a birthday photograph to the wall of her living room) compared to his more liberated asymmetry as he playfully swings randomly around on the shop's stock cart. Another shot of Patrick walking down the centre bank of a dual carriageway, echoes in its composition the earlier shot of Karen walking up the centre of O'Connell Street in her Aer Lingus hostess uniform.

McMahon's dialogue is noteworthy in his general tendency to stifle any sentimentality that might soften characters problematic relationships, or shortcut audiences' response to the characters and their situation. While I have noted the controlled and brusque dialogue used in the first scene between Patrick and Karen (at the end of which she bursts his balloon), this tendency in the writing is carried over most notably in John Freeman's turn of phrase. Selfidentified in his stated preference for a certain kind of one-liner joke, Freeman says: "You see, I prefer the ones where the punch line is part of the joke itself," and goes on to betray insensitivity towards those suffering with schizophrenia. His disparaging language about the mentally ill, expressed as it is by other similar characters whose speech is awkwardly littered with the words "they" and "these people", 
serves further to define positions of institutional insiders and outsiders: people marked as pariahs in their social marginalisation and ostracisation, and the attitudes of those implicated in that alienation.

It is likely that some might charge McMahon with pandering to American audiences in his deployment of Irish (American) cultural iconography throughout the film. However to deny the usefulness of these commodified cultural contact points would be to reject the economic imperatives that face any filmmaker confronting the realities of the transnational cinematic financial networks. What is important, as McMahon shows us the Saint Patrick's Day parade and its paraphernalia, the famous speech made by JFK to the Dublin parliament in 1963, the "Discover Ireland" board game, the immediately identifiable music on the soundtrack, and even the very title of the film, is that he restrains their metaphorical connotations so that none becomes mere moment of cultural kitsch. At every juncture the writer-director fine tunes and regulates his characterisation, mise-enscène and dialogue, with a precision that subtly positions the audience in an empathetic relationship with the eponymous protagonist and the world in which other characters may implicate us in the ignorance and alienating complicity of the characters who surround him. It is a daring, and risky, venture, but not unprecedented in the history of film narrative, at which moments writers and directors have decided that the relegation of audiences' identification with secondary characters is necessary for creating empathy with a protagonist with whom consideration, or emotional connection, is not so easily accomplished. McMahon courageously presents Patrick's situation not only indirectly for us through his cinematic narration, but acutely, directly by aligning our experience of the personalities who surround Patrick, with his understanding of the same people.

Barry Monahan lectures in the history and aesthetics of Irish and other national cinemas, and film theory, at University College Cork. His recent monograph Ireland's Theatre on Film: style, stories and the national stage on screen, published by Irish Academic Press in 2009, considers the relationship between the Abbey Theatre and cinema from the beginning of the sound period until the 1960s. 
Irish Film Finance Rebooted: The New Section 481

Denis Murphy and Maria O'Brien

\section{Introduction}

2014 saw the winding down of one of the most popular tax write-offs for Irish individuals, as the Section 481 state film subsidy transitioned from an investor-led to a so-called producer-led structure, following a review of the scheme by the Department of Finance. In reality, the incentive might be more appropriately classified as exchequer-led, as State largesse continues to underpin the scheme, by some measure the most significant market support mechanism subsidising film, TV drama, documentary and animation production in Ireland.

Since its inception in 1987 as Section 35 of the Finance Act 1987, the relief has played an important role in attracting private investment into the Irish film industry. It is relevant that the introduction of the relief coincided with the Irish Film Board's six year hiatus before its reinstatement in 1993. This juxtaposition underscored a shift in film policy away from the encouragement of low-budget, indigenous arts activity and towards a more outward-looking commercial-industrial concept. Over the years, the value of the relief for an individual project has increased significantly and is now worth up to 50 million euro, depending on the amount of overall Irish expenditure. While this amount is large in Irish terms, it is unremarkable by international standards: the comparable UK scheme has no limit, for example (BFI 2015). The cap remains unchanged since 2008. Indeed the industry has been lobbying for an increase, and the Minister for Finance has committed to keeping the scheme under close review (Brosnan 2015).

\section{The 2015 changes}

Apart from the relatively superficial switch from an investor-funded to a tax-credit structure, there are several major changes affecting Irish film industry practitioners. First, the scheme can now contribute up to 32 percent of eligible expenditure on qualifying projects (an increase from 28 percent under the previous version). Second, the definition of eligible expenditure has been expanded to include the cost of all cast and crew working in Ireland, regardless of nationality. This change, dubbed the "Tom Cruise clause" by the Irish press even before the new regulations came into operation in January 2015, removes the previous limitation to cast and crew from the European Extended Economic Area (EEA) (Webb 2013).

This has important potential implications for film workers, as does a third change, whereby S481 certification will now be granted to the production company ("producer company") itself rather than the one-off company ("qualifying company") established to produce the film. The producer company is not required to be Irish resident; it can be based anywhere in the EEA, as long as it carries out business in Ireland through a local branch or agency. As under the previous version of the scheme, S481 productions nevertheless require an "Irish-based" producer, co-producer or executive producer, who must be credited as such in the film titles. An interesting addition to the legislation is the stipulation that the producer company must be in the business of making theatrical or television films "on a commercial basis with a view to realisation of profit" (Revenue 2015: 8). In a further modification, the new legislation specifically excludes broadcasters and Internet based VOD companies such as Netflix.

The main procedural changes to S481 lie in the logistics of claiming or obtaining payment. One of the advantages of the old version was that funds raised were available from the first day of 
production. The new structure, with funding granted as a credit against a company's end-ofyear corporation tax liability, was greeted initially with a degree of trepidation, as it was unclear how production cash flow might be affected (e.g. O'Neill 2013: 93). The Revenue Commissioners have subsequently provided some clarification on this: while producers may defer payment until completion of the film, they also have the presumably far more useful option of receiving payment in two instalments: 90 percent in advance, and 10 percent on completion of production (Revenue 2015: 16-17). It is as yet unclear, however, how quickly Revenue will pay this first instalment. According to their published guidelines, "any payment due will be transferred....no earlier than seven days after the issue date of the certificate" (ibid: 5, our emphasis). However the fact that seven days is the minimum period, with no maximum given, leaves open the possibility that producers may require recourse to alternative funders to bridge this gap.

A further concern was whether a tax credit would be of much practical use to a producer companies with a corporation tax liability lower than the maximum relief available. Helpfully for such companies, the full credit can still be claimed, provided the company has no other outstanding taxes (ibid: 1, 4).

\section{Implications}

One of the more significant changes to S481 down through the years was the 1994 requirement that all funded projects be certified by the Minister for Arts, Culture and the Gaeltacht (now Arts, Heritage and the Gaeltacht), and the introduction of a 'cultural test' as part of the certification process. Prior to this, there was no formal requirement that S481-funded filmmaking activity have any relevance at all to Ireland or Irish culture (thus, for example, allowing a film about a $13^{\text {th }}$ Century Scottish folk hero - Braveheart - to draw down millions of punts of S481 funding). The test was thus formulated with some form of territorial protection in mind. However, bearing in mind the fundamental aims of the tax incentive, namely to promote both inward investment and indigenous development, the test was drafted in as wide a manner as possible. Given the expansion in scope represented by the 2015 changes, it is perhaps surprising that this cultural test remains unchanged.

With the new Section 481 in effect only since January 12,2015 , it is of course far too early to assess their impact on the industry. One suspects that certain changes, such as the specific exclusion of broadcasters and netcasters from certification, is a response to certain ambiguities in the old regulations. However the new regulations engender a number of new ambiguities, prompting some reservations in trade union circles especially about the implications for Irish film workers - including Irish producers. ${ }^{1}$ By design, Section 481 has always functioned as an incentive for mobile international film capital to locate production in Ireland. While the new regulations continue the requirement for the participation and accreditation of an "Irish based" producer, there is no stipulation that he or she be attached to an Irish production company. In practice, incoming producers have tended historically to outsource Irish production in whole or in part to a local coproducer, whose duties typically have included the application for Section 481 certification; compliance with the conditions of same; and the hiring and management of local crews. It is of course possible that Irish production companies will continue to provide the "agency" required by the legislation, and that indeed is the Irish Film Board's recommendation (IFB 2015). There is nothing in the letter of the law, however, requiring the participation of an Irish production company that might come under the remit of SPI and its labour agreements with Irish film unions.

Added to this, the Tom Cruise clause's removal of the EEA limitation removes with it the incentive to hire EEA cast and crew. In theory at least, a production company could function with no Irish or European workers, beyond the scope of established labour agreements, and with few obligations to workers beyond the minimum wage and health, safety and working time standards. That such a situation is

1. Personal interviews with trade union officials, Sept 2014. 
at least theoretically possible is a stark reminder of the precarity inherent in the new international division of cultural labour (Miller et al 2005). Also, perhaps, it explains and justifies the "cultural test" requirement that certifiable projects function as "an effective stimulus to film making in Ireland” (Revenue 2015: 7).

In relation to production cash flow, the increase in producer benefit from 28 to 32 percent arguably compensates for the inconvenience of getting only 90 percent of the relief up front. It is nevertheless likely that some producers will access bridging finance to plug this gap. One of the reasons for revising the format of the relief was to minimise 'leakage', namely the difference between the amount of tax forgone by the exchequer and the amount of finance received by the production. However, the costs associated with this bridging finance, and the possibility that producers, under certain conditions, might require a surety bond to access the 90 percent upfront payment, could mean a certain amount of leakage may still take place (ibid: 17). As a result whilst bringing clarity to some areas of the funding mechanism, the new regulations also introduce some new uncertainties: how the new S481 will play out in practice, only time will tell.

\section{Works Cited}

BFI 2015. UK film tax relief summary [ONLINE]. Available at: http://www.pinewoodgroup.com/sites/default/files/ps-pdfs/pwd_uk_film_incentive_summary.pdf [Accessed 5 Mar 2015].

Brosnan, Seán. 2015. "New tax incentives to bring Ireland in line with the UK and other European Countries". IFTN [ONLINE], 7 January 2015. Available at: http://www.iftn.ie/news/?act1=record\&only=1\&aid=73\&rid=4287906\&tpl=archnews\&force=1g [Accessed 5 Mar 2015].

IFB 2015. Financing your film/Tax Incentives/Section 481 [ONLINE]. Available at: http://www.irishfilmboard.ie/financing_your_film/Section_481/5 [Accessed 2 Apr 2015].

Miller, Toby, Govil, Nitin, McMurria, John, Maxwell, Richard and Wang, Ting. 2005. Global Hollywood 2. London: BFI.

O’Neill, Declan. 2013. "Finance Act 2013: film tax relief changes”. Irish Tax Review 26 (1), pp.90-93.

Revenue 2015. Guidance note for application for "section 481" relieffor investment in film [ONLINE]. Available from http://www.revenue.ie/en/tax/ct/leaflets/application-for-film-investment.pdf [Accessed 27 Feb 2015].

Webb, Nick. 2013. "Dracula horror as North lures \$70m movie from Ardmore". Irish Independent [ONLINE], 19 May 2013. Available at: http://www.independent.ie/business/irish/dracula-horror-as-north-lures-70m-moviefrom-ardmore-29277950.html [Accessed 5 March 2015].

Denis Murphy is a doctoral candidate at the School of Communications, researching the labour history of Irish film production. He previously worked in TV, film and multimedia as an editor, producer, and director.

Maria O'Brien is a doctoral candidate at the School of Communications, Dublin City University. She is researching fiscal incentives within the animation and gaming industries. She previously worked as a solicitor for 10 years and holds a M.A in Screen Studies from Goldsmiths, University of London in 2007 and a M.Litt from Trinity College Dublin. 


\title{
Frank (Lenny Abrahamson 2014)
}

\author{
Harvey O'Brien
}

\section{"Someone is thinking in the key of C!"}

A wannabe musician comes into contact with an inspirational artist who wears an oversized fake head that he never removes. There's some factual truth in that part of it. Journalist Jon Ronson, cowriter of the screenplay for Lenny Abrahamson's Frank, did briefly play keyboards with Frank Sidebottom's 'Oh Blimey Big Band' in the 1980s. He recounted these events in a memoir: Frank: The True Story that Inspired the Movie, published in book form to coincide with the release of the film. "Inspired" is an important word in that sub-title, and also in the film. Frank is about inspiration, and where and how to find it. As in all of Lenny Abrahamson's films, the answer is found in profound and genuine respect for other human beings.

What initially seems an unlikely follow up to What Richard Did (2012) reveals itself as a confidently funny and moving serio-comic drama directly in a line of thought and expression with Adam and Paul (2004) and Garage (2007). At its heart is Abrahamson's characteristic humanism framed by the steady gaze of a curious but nonjudgemental camera. Not everyone sees the world the same way, and Abrahamson's gift has always been to assert this without resorting to moral relativism or cinematic cliché. He navigates the maps of genre at the edges, miraculously maintaining a mix of familiar and challenging movements. The Beckett-like qualities of this complex simplicity has been noted in relation to Adam and Paul and Garage. His use of space, silence, and sparse but clear and pointed characterisation gave a kind of classicism to the ordinary that struck a chord through the last days of the Celtic Tiger.

Putting hunky German-Irish actor Michael Fassbender in a giant fibreglass head for almost the entire movie of Frank pretty much sums up that alchemy of fun and daring that we might also recall from Beckett's Happy Days or Endgame, with its protagonists absurdly situated in unlikely physical situations, but no less reflective or expressive, funny, tragic, and human, for all that. It's patently true that the world as seen through a giant head must look a little different, but of course it is we who are looking at Frank looking at us through the medium of James Mather's camera as directed by Abrahamson from Ronson and Peter Straughan's screenplay.

But let's be clear about one thing from the outset, the film Frank is not a biography of Chris Sievey, the Mancunian musician-performer who died four years before the film's release. It's not even about Frank Sidebottom, the papier-mâché head-wearing character Sievey created and performed through the 1980s from the punk music scene where he played a ukulele to increasingly near mainstream fame on British television with Frank Sidebottom's Fantastic Shed Show in the early 1990s. Rather, it takes that character, a surrealistic nonconformist with an irrepressibly determined if slightly loopy outlook, and creates an entirely original fictional drama around what a world with a real Frank in it might be like. There is no Sievey inside this Frank's oversized head.

Sievey had actually been aware of the early scripts before his death, and was reportedly enthusiastic about where it was all going. The film is 'about' Sievey's Frank only insofar as the premise of there being such a creature as Frank is given credibility because there really was one. But the film is about the imagination such a figure inspires rather than the mundane facts of 'what really happened'. According to Ronson, there is only one line in the script that recounts an actual conversation, when Don (Scott McNairy), the band manager, asks young Jon (Domnhall

ISSN 1699-311X 
Gleeson) if he can play $\mathrm{C}, \mathrm{F}$, and $\mathrm{G}$ on his keyboard, and when he says yes he's told "You're in." Before the film was even released, the blogosphere was alive with cries of distortion. 'Americanising' Frank Sidebottom, cult hero, to pander to an international cinema audience, Abrahamson was prejudged guilty of all kinds of heresies. Never mind that it was always clear the script was fictive and never intended to be either a biography or a music industry tell-all: the internet is often a wilfully ignorant and consistently hysterical place. Abrahamson, who maintains a robustly active Twitter account of his own, was forced to respond to a great deal of hostility from 'fans' professing to defend Sievey's legacy.

This was, in fact, a prescient preview of one of the film's thematic threads, where imaginative purity is polluted by the desire for popular acknowledgement. When Jon tries to bring the band out of the literal wilderness (the holiday cabin in deepest, darkest Ireland where Soronprfbs (the band) retreat to record an album of totally original character) and into the public gaze at the SXSW South by Southwest music festival in Austin, Texas, it shatters the bubble of desperate fringe artistry in which this group of outsiders have deliberately remained. In a classic generic trajectory of the band movie, the 'sellout' nearly destroys them, although it may also provide the catalyst for a realpolitik catharsis for Frank himself. The film ends with the very human Frank (without the head) singing a heartrending ballad, "I love you all" (written by Stephen Rennicks, as all of the film's off-thewall music was) and staring into his lover Clara's (Maggie Gyllenhaal) eyes for the first time. Meanwhile Jon, Ethan Edwards-like, walks away into the American wilds, leaving behind a family he could never really be part of.

The film begins with Jon struggling to assert his voice as a musician at his bedroom computer in the family home he truly belongs in: an ordinary suburban one complete with dinnermaking Mum (\#nomnomnom). Coming home from the seafront (Bray: standing in for nowhere, England), he thinks he has found inspiration in a song condemning that dreary, pedestrian world for its lack of imagination, only to realise he is playing the chords from "It must be Love" by Madness, which he has just heard on the bus over someone's headphones. It is a genre cliché that the musician resents his point of origin as he searches for originality, and an even more entrenched convention that he is right to do so. Frank firmly but gently overturns expectation at the film's climax, where after a spectacular bustup in which a mentally collapsing Frank has fled and his head has been literally broken into pieces (the fake one, naturally), Jon tracks him to his family home in Bluff, Kansas (Wizard of $\mathrm{Oz}$ country). Here again we find an ordinary home with ordinary, decent people - Frank's caring and regular parents concerned for their son, and seeing more clearly than anyone that the myth of artistic torment doesn't explain him. "Torment didn't make the music," Frank's mother (Tess Harper) tells Jon, "He was always musical. If anything, it slowed him down." Jon finds himself realising the humanistic truth at last. 'It's a good home," he says, "It's just like my home."

Jon's delusion is that he thinks he can learn to see the world through Frank's eyes, and so unlock his own creativity. He wonders as Frank encourages the band to create their own musical instruments. He ponders as Frank navigates the world with feeding tubes and a 'certificate' that allows him to pass through security checkpoints unmolested. He marvels as Frank talks (unheard, and in long shot) to a German holidaymaker whose rental cottage the band has unlawfully occupied beyond their term, and who leaves crying with joy, waving, and shouting "Thank you for this new truth in my soul". But as we are directly told "There can only be one Frank", and Frank, real as he is both with and without the head, can only be himself. When he sings "I love you all", he's not kidding, and it's not faux Hollywood redemptive ennoblement of the audience. Jon eventually comes to realise that truth and inspiration can only come from love, and cannot be tricked or faked into being by affecting the rituals of artistic behaviour. When Jon makes his exit and leaves the band behind, he has genuinely only just begun to learn that he even has a soul, and where and in what it must be rooted.

Abrahamson's impulses are demythologising, 
but generous. He is receptive to and giving with the generic pleasures of a comical road movie about a band of misfit musicians, and the film is physically and verbally funny. There are broadstroke comical sight gags that are inevitable given the cartoon-like appearance of Frank, but Abrahamson films without excessive exaggeration, and this gives the comedy a dramatic underpinning. When suicidal Don runs naked for the country lake in an attempt to drown himself only to be brought down first of all by full-headed Frank, then by a wooden log lobbed from great distance with pinpoint accuracy by an impassive Clara, the scene plays out again in unsensational long shot. Even though the central character looks like a cartoon, the director and his writers never settle for caricature. Each 'type' we meet quickly deepens in detail, and textbook 'quirks' are never played entirely for casual laughs. Even Don's bizarre sexual predilections take on a sombre sentiment as he performs a sad, poetic song for Jon using his keyboard, and then immediately casually dismisses this cri de coeur as musical failure. When Don announces "We're done" when they finish recording the album, we are in no doubt of the depths and levels of meaning that simple expression bears for him. We are not surprised, but are very much moved, when the thought-line is followed to its inevitable resolution. Even Maggie Gyllenhaal's rather terrifying überbitch, who stares her way contemptuously through the whole film, seems merely clear-sighted and direct when viewed in context. She stabs Jon precisely as she warned him she would, and in spite of his dollar-book Freudian' reading of her sense of possession of Frank, the film duly reveals a deep seated interconnection between her soul and Frank's, without ever getting overly explicative about it.

There's an indisputably grotesque and absurd side to it all, but the film is never far from the dark places we know this director can go to. There's also uncompromising satire and selfawareness in the depiction of the shallow world of internet celebrity, seen most crushingly when Frank's on-stage breakdown becomes just another 'hilarious' bit of 'wayward stuff' that amuses the fickle click-bait community. It's where and when the film refuses verbalisation that we see the cineaste's eye standing back wit a much wider view of these people than sentimental empathy could afford, and here when yet again Abrahamson makes us aware of our spectatorial participation in ways that enrich the entire viewing experience. We cannot be Frank either. As in What Richard Did, Abrahamson follows impartially, his camera roving like the opening of Citizen Kane over the gates of Xanadu and into a world filled with other humans that we can watch, but not occupy.

Frank is also a sonic experience, naturally, and Stephen Rennick's songs are pretty much bangon as a mix of out-there goofiness and 'likeability'. The inverted commas refer to a particular gag in the film where Frank, pleased with the idea of popularity (people who "know and love us") and driven by Jon's advice to make the sound a bit more accessible to the SXSW audience, composes his "most likeable song ever" to the immense horror of the rest of the band. All through it, Rennick provides a soundscape filled with eccentric joy, from the surprisingly catchy 'Ginger Crouton' with Fassbender's Jim Morrison-like slam poetry delivery to the rather lovely 'Lone Standing Tuft' performed first with solo guitar, and the climactic 'I Love you All' which really ought to have been up there at the Oscars.

Frank's singing is performed by Michael Fassbender, who renders the songs with impressive tonal expressivity underneath the head. His bodily interpretations are not just wild gesticulation, but articulated eurythmics that work with the scale of the head, but which also demonstrate again a depth of characterisation. When Frank breaks down on stage, he has been standing largely static - paralysed by conflict and compromise. When he rehearses with the band in the Irish wilds, urging Jon ("ginger bird") to lay and egg for him, or conducting exercises in musical imagination including sprinting while trying to avoid thinking in the key of C, Fassbender is all action - a wild conductor that holds the centre of a potentially chaotic melee. It's a good performance by any measure, given an added cheeky twist by the presence of the head, but again the director and performer have not stopped at high concept and remained pleased 
with their own cleverness. Frank is a fully realised film entertainment, well crafted and well executed, with both humour and drama that doesn't easily let go of the imagination. If the strains of "I Love you All" aren't ringing in your ears after you've seen it, then at least the image of the inscrutable head staring back at you will, and you'll wonder if there's a 'welcoming smile' underneath.

Harvey O'Brien is Lecturer in Film Studies at UCD, Dublin. His most recent book is Action Movies: The Cinema of Striking Back (Wallflower/Columbia University Press, 2012). 


\section{Quirke (TV Mini Series 2014)}

\section{Sheamus Sweeney}

Quirke is the indirect offspring of two recent developments in television crime drama. In one respect it appears pitched at the audience that embraced the rise of Scandinavian crime drama; Nordic noir like Wallander (2005-2013), Bron/The Bridge (2011- ), and Forbrydelsen/The Killing (2007-2012). This is evident in its relatively high production values, stories of institutional wrongdoing, graphic content, ambivalent conclusions and other markers of quality television. Central to these is the series origin in the crime novels of John Banville (writing as Benjamin Black), which gift it an inflected literary pedigree. Like the SwedishDanish co-production of Bron/The Bridge it is also an international drama, through the context of its production and financing. Three ninety minute episodes were co-produced by the BBC, with the Irish companies Tyrone Productions and Element Pictures, and a $€ 450,000$ production loan from the Irish Film Board (Cummins 2012). Initially slated for broadcast on RTE1 and BBC1, there were reported pre-broadcast sales to five other European countries (Barraclough 2014).

The BBC element is particularly important as Quirke most comfortably fits into another relatively recent development; the increasing popularity of the British period crime drama. While this sub-genre has long been a popular television presence more recent examples like Inspector George Gently (2007- ), Foyle's War (2002-2015), Endeavour (2012- ) and more recently, Grantchester (2014- ) all foreground a tendency to revisit the social history of the periods in which they are set. Quirke also shares with most of these a preference for short runs of three or four feature length episodes, a format inaugurated by Inspector Morse (1987-2000), of which Endeavour is a prequel, and which Foyle's War was intended to replace in the schedule (Nicholas 2007: 207). These dramas are aimed at an older audience than the one for the latest Nordic noir. However, the original Swedish version of Wallander, dubbed "Norse Morse" by one critic (Tapper 2009: 60), would not look particularly out of place on the all-crime cable channel Alibi. Furthermore, Foyle's War, for all of its connotations of cosy crime and wartime nostalgia, initially used its period setting to revisit, revise, and disinter marginalised narratives of anti-semitism, pacifism, communism, and xenophobia (Nicholas 2007). Ireland, specifically Dublin in the 1950s, would seem a prime space and place for such dramatic exploration. The decade sees the postindependence Catholic and conservative political, economic, and religious establishment at the height of its power. Kate Warner's (2009: 729) argument that "in many cases the model of investigation used in detective shows is set up to specifically echo that of historians" seems particularly apposite in the case of Quirke (Gabriel Byrne). Quirke is a pathologist who dissects the bodies of dead women to uncover which particular cultural or historical hypocrisy killed them. In common with other dramatic revisiting of the past, these discoveries often make veiled references to current preoccupations. Quirke's first episode, Christine Falls, re-treads familiar ground of abuse and illegal adoption in religious run institutions.

Like most amateur sleuths, Quirke is drawn into investigations seemingly against his better judgement, by a mixture of curiosity and circumstance. He is an outsider, a Heathcliff type foundling, and a non-believer adrift in a sea of self-serving piety. This status is underlined in the opening credits, where he appears as an indistinct outline, and the space where his body should be is filled with events and images from the upcoming episodes. The streets of Dublin appear suitably grainy, rainy and noir-like. Like his adopted

ISSN 1699-311X 
brother Malachy, an obstetrician, Quirke is a doctor, but ministers at the opposite end of the life cycle. Oscar Latimer, who appears as brother of the titular missing woman in the third episode, Elegy for April, is also an obstetrician. All three exercise dominion over women's bodies, although in Quirke's case the seeming exclusivity of his focus is due more to crime fiction convention than to any subjective bias of his own. The opening scenes of the first two episodes feature women's bodies laid out on a slab in his mortuary. The second episode, "The Silver Swan", opens with a middle class woman, complete with fox fur stole, sitting dead in a car, a shoe hanging off her stockinged foot and top blouse button undone. The sexualisation of her corpse is especially, and possibly deliberately, jarring, as it is followed immediately by her graphic post-mortem.

In terms of its dramatic quality and thematic coherence, Quirke's limited run of three episodes is uneven. While it attempts reasonably faithful adaptations of source material with a specifically Irish focus, the subject matter is the raw material of most crime fiction; conspiracy, corruption, blackmail, sexual jealousy and institutional wrongdoing. Unfortunately, even in comparison with a drama like Foyle's War, there is little sense of thematic boundaries being tested, or the presentation of a newer perspective on familiar events. The revelation of illegal adoption practices within mother and baby homes is not particularly revelatory, nor is its augmentation by a conspiracy plot involving wealthy and powerful men. It is worth acknowledging that the plot may have had more edge in its 2006 source novel, which was based on an abandoned mini-series mooted for co-production by RTE and the Australian Broadcasting Corporation (ABC) (Independent.ie 2014).

The uneven tone is also apparent in The Silver Swan, which abandons the broader themes of the first and third episodes for a generic sexual blackmail plot. The episode has a placeless quality and could easily slot into any number of crime drama series. Respectable middle class women are induced, under the influence of drugs, to undress for nude photographs which are used to blackmail them. Yet this is not the episode's most troubling element, underlined by its Irish setting, as the two main corrupting influences in the story are foreign. Lesley White is an English drug-addict, libertine and embezzler, who steals from his business partner Deirdre Hunt. The drug dealer and pornographer who persuades women to undress for his photographs is Hakim Kreuz, and is clearly signalled as a native of the Indian subcontinent. In the book he is described as partGerman, but no such qualification is present here. Therefore Catholic middle class respectability is outraged by two sleazy foreigners, presented as straightforwardly corrupt and self-serving, without a hint of nuance or mitigation. The only element that potentially undermines this reading is the implication that Deirdre Hunt, an uppity working class Dubliner, is partially the architect of her own downfall.

The milieu of the novels and adaptations is that of the 1950s Catholic upper middle class, whose worldview, and the dramas themselves, is largely bounded by affluent Dublin south of the river Liffey. This is humorously adverted to by Quirke's incrementally acquired northsider sidekick, Inspector Hackett (Stanley Townsend), who jokes about being in south Dublin without his passport. Despite initially appearing as an identikit clueless copper, his silences and tendency to understatement slowly reveal a character who understands the institutions he confronts far better than Quirke. He does what he can, within the boundaries that Quirke consistently oversteps. His development stands in stark contrast to Quirke's estranged daughter Phoebe Griffin (Aisling Franciosi), a plot device masquerading as a character, who alternates between potential victim and plot catalyst. In Christine Falls she is revealed both as a partial explanation for Quirke's own dysfunction, and as the seed from which a larger conspiracy evolves.

In an interview published as the series aired on BBC1, Gabriel Byrne describes the churchdominated society of the time as "Talibanesque" (Independent.ie 2014). Banville suggests that "the Catholic Church was our [the Irish] Communist Party" (ibid). The narratives themselves seem to cut against such statements. What is striking about both Elegy for April, and Christine Falls in particular, is the marginal role played by the institutional church. The adoptions that form the core of the plot are initiated and 
sustained by a lay organisation, the Knights of Saint Patrick. The role of the religious orders at either end of the adoption supply chain is effectively warehousing and logistics, mirroring the transport business of Quirke's American father-in law. His father, Judge Griffin, is a papal knight. The plot climax in Elegy for April takes place as another lay organisation, Corpus Christi, meets to honour a veteran of the War of Independence. This is one of the stronger recurring tropes within the series; religion as a fundamentally social and political infrastructure to reproduce and maintain power in the hands of a self-selecting elite.

Even granted the need to appeal to international audiences, neither of the first two episodes rises much above the level of melodrama. The only part of "Christine Falls" with a ring of truth is its conclusion where Judge Griffin suggests that the police will only laugh if Quirke, his adopted son, starts telling tales of illegal adoptions and abducted babies. In "The Silver Swan" it is revealed that the adoptions investigation has been quietly dropped. Both were written by veteran screenwriter Andrew Davies, whose credits include the original House of Cards (1990) and the 1995 BBC adaptation of Pride and Prejudice. There is little in either episode to really engage an Irish audience, or for that matter any audience accustomed to better executed dramas about personal or institutional corruption. The partial exception to this is the third episode, Elegy for April, written by playwright and screenwriter Conor McPherson (The Seafarer (2006) and I Went Down (1997)).

The writing in this episode is characterised by its attempted exploration of the legacy of the generation who won independence. It engages with their financial, political, and media power, and the revolution's degeneration into censorious morality and self-interested silence. These elements emerge through Quirke's investigation into the disappearance of April Latimer, independent-minded daughter of a prominent Fianna Fail family. It reveals the effects of a psychic disfiguration caused by the struggle for independence, which is then transmitted through the generations. It is not the most nuanced of symbolic representations, but is welcome as an exploration of the nature of Irish political dynasties.
It is perhaps unsurprising that McPherson has more of a feel for the historical period than Davies, and he approaches it primarily as an Irish drama with crime elements, rather than as a crime drama.

Elegy for April, while not without problems, stands qualitatively apart from the others. It opens without a body, focussing in its teaser sequence on the trembling figure of the alcoholic Quirke, drying out in a religious run institution. The contradictory class politics of republicanism are hinted at. When Quirke and Hackett visit Celia Latimer to discuss her daughter's disappearance, she speaks only to Quirke, son of a High Court judge, and ignores the working class Hackett. By contrast her brother-in-law, as befits a minister on the cusp of the pragmatic and technocratic Lemass era, treats Quirke with open contempt, as only Hackett has professional competence in the area. McPherson's script is strengthened by other narrative and visual details. In an early scene Quirke listens to a de Valera speech on the radio addressing "the twin evils of unemployment and emigration", a theme bound to resonate with the television audience. When Phoebe's journalist friend, who works for the de Valera controlled Evening Press, writes a story about April's disappearance, he is sacked. At the conclusion of the episode he writes the full story, but this time for the Irish Times, formerly the voice of protestant unionism, and without any party affiliation. On both occasions the papers' mastheads figure prominently. Patrick Ojukwu, a doctor from Benin, is introduced as part of the social group including April Latimer and Phoebe Griffin. While his presence mostly adverts to the continuity of racism within Irish society, it also suggests the possibility of miscegenation within the Latimer family. Incest, Malachy Griffin presciently observes, would undoubtedly be seen as a lesser evil.

The how and why of women's death constitutes the raw material of the plot in all three episodes, as it does in much crime drama. In the case of April Latimer, it turns out that she died as the result of a botched abortion. In The Silver Swan, Deirdre Hunt is murdered by her husband, in what can only be described as an honour killing. He reflects, "It's the women isn't it. It's always the women. What they do to us, what we do to 
them." It is a line worthy of sentimental misogynists everywhere. Unfortunately, the women not despatched violently are treated little better. Sarah Griffin, Quirke's sister-in-law, and the love of his life, dies in the second episode, for seemingly no other reason than to deny him happiness after they belatedly sleep together. Phoebe occupies almost as much screen time as Quirke, but has no narrative of her own, and her storylines centre on sexual encounters that leave her respectively traumatised, manipulated, or rejected. The one potential counterpoint is the actress Isobel Galloway, whose response to Quirke's desperate plea for help is to drive him back to the alcohol clinic and leave him there.

Raphael Samuels (1994: 657) argues that "our understanding of the historical past is constructed not so much in the light of documentary evidence, but rather of the symbolic space or imaginative categories into which representations are fitted." As a crime drama Quirke largely stays true to genre convention by eschewing a wider societal critique, something to which Irish crime drama would be particularly amenable, given the of the problem with crime drama is that a formalistic adherence to generic constraints and tropes tends to predominate. This is also apparent in the Banville-Black novels, and of course these formal elements form part of the genre's attraction. Of equal importance is the difficulty of balancing the need to make an export-friendly drama, while still attempting to say something about a country whose audience is of limited commercial import. While the final episode of Quirke was partially successful in this regard, for British and other audiences it has too little to distinguish it from the plethora of dramas about detectives in hats that clog up their own screens. This is underlined by $\mathrm{BBCl}$ 's decision to schedule it almost as something of an afterthought in May 2014, four months after it aired on RTE. In spite of the faults identified here it would be unfortunate if, as seems likely, Quirke does not return, and not only because of the potential for development apparent in its final episode. It is also one of the few counterpoints to Irish television's seemingly insatiable desire to equate urban Ireland with either a vacuous middle class, or a violent underclass.

\section{Works Cited}

Barraclough, R. 2014. “007 creator drama Fleming spies sales with BBC Worldwise”. Variety [Online], 20 January. Available from: http://variety.com/2014/tv/news/007-creator-drama-fleming-spies-sales-with-bbc-worldwide1201065463/ [Accessed 6 March 2015].

Cummins, S. 2012. "Gabriel Byrne to shoot BBC crime thriller Quirke in Dublin”. The Irish

Film and Television Network [Online], 27 August. Available from: http://www.iftn.ie/news/?act1=record\&aid=73\&rid=4285270\&tpl=archnews [Accessed 6 March 2015].

Independent.ie. 2014. "Gabriel Byrne returning to Dublin for second series of Quirke". Independent.ie [Online], 22 May. Available from:

http://www.independent.ie/entertainment/tv-radio/gabriel-byrne-returning-to-dublin-for-second-series-of-quirke30295762.html [Accessed 6 March 2015].

Nicholas, S. 2007. "History, revisionism and television drama: Foyle's War and the 'myth of 1940'”. Media History, (13) 2/3, pp.203-219.

Samuels, R. 1994 [2012]. Theatres of memory: past and present in contemporary culture. [Kindle edition] London: Verso.

Tapper, M. 2009. “"More than ABBA and skinny dipping in mountain lakes': Swedish dystopia, Henning Mankell and the British Wallander series". Film International, (7) 2, pp.60-69.

Dr. Sheamus Sweeney lectures on media and communications to Boston University's Dublin Programs hosted by Dublin City University. In 2013 he was awarded his doctorate for a study of David Simon's HBO series The Wire. 